\title{
Dye-Assembled Nanocomposites for Rapid Upconversion Luminescence Sensing of $\mathrm{Cu}^{2+}$
}

Xiaohua Huang ${ }^{\mathrm{a} 1}$, Lijia Wang ${ }^{\mathrm{a} 1}$, Xiaojun Zhang ${ }^{\mathrm{b}}$, Xuehua Yin ${ }^{\mathrm{a}}$, Na Bin ${ }^{\mathrm{a}}$, Fenfen Zhong ${ }^{\mathrm{a}}$, Yingju Liu ${ }^{\mathrm{c} *}$ and Qingyun $\mathrm{Cai}^{\mathrm{a} *}$

${ }^{a}$ State Key Lab of Chemo/Biosensing\&Chemometrics, College of Chemistry \& Chemical Engineering, Hunan University, Changsha 410082, China

${ }^{b}$ Changsha Power Supply Company of State Grid Corporation of China, Changsha, Hunan 410010, China

${ }^{c}$ Department of Applied Chemistry, College of Materials and Energy, South China Agricultural University, Guangzhou 510642, China

*Corresponding author. E-mail: qycai0001@hnu.edu.cn, qycai0002@gmail.com (Q. Cai). liuyingju@hotmail.com (Y. Liu).

${ }^{1}$ These two authors contributed equally to this study and share first authorship.

\begin{abstract}
An upconversion luminescence probe for the detection of $\mathrm{Cu}^{2+}$ is constructed by assembling meso-tetra(4-sulfonatophenyl)porphine dihydrochlorid (TSPP) on $\mathrm{SiO}_{2}$-encapsulated $\beta-\mathrm{NaYF}_{4}: \mathrm{Yb}, \mathrm{Er}, \mathrm{Gd}$ nanorods which were synthesized by hydrothermal reaction and encapsulated with a layer of ultrathin silica through a water-in-oil reverse microemulsion strategy. Under excitation of $980 \mathrm{~nm}$, the nanorods emit upconversion lights at $545 \mathrm{~nm}$ and $659 \mathrm{~nm}$, respectively. While in the presence of $\mathrm{Cu}^{2+}, \mathrm{Cu}^{2+}$ forms complex with TSPP, which shifts the maximum absorption of TSPP from 515 to $545 \mathrm{~nm}$. As the maximum absorption of TSPP-Cu ${ }^{2+}$ is overlapped with the emission at $545 \mathrm{~nm}$ of the nanorods, the luminescence energy of the nanorods can be transferred to TSPP- $\mathrm{Cu}^{2+}$ complex, resulting in a quench of the emission at $545 \mathrm{~nm}$, while the upconversion emission at $659 \mathrm{~nm}$ is not affected by $\mathrm{Cu}^{2+}$, and can be used as a reference. $\mathrm{Cu}^{2+}$ was therefore quantified based on the ratio of the upconversion luminescence at 545 to that at $659 \mathrm{~nm}$. Using the ratiometric
\end{abstract}


upconversion luminescence as detection signal, the nanoprobe shows high selectivity and sensitivity towards $\mathrm{Cu}^{2+}$ with a limit of detection of $2.16 \mu \mathrm{M}$, and a quick response time of within $10 \mathrm{~s}$. The analysis of $\mathrm{Cu}^{2+}$ in Hela cell lysates indicates the potential applications of this nanoprobe in the near-infrared fluorescent imaging of $\mathrm{Cu}^{2+}$ in cells.

KEYWORDS: upconversion luminescence, LRET, $\mathrm{Cu}^{2+}$

\section{Introduction}

Copper is a transition element essential to human health. In particular, $\mathrm{Cu}^{2+}$ is a cofactor for many protein enzymes and it plays a significant role in numerous physiological processes in the human body [1-4]. However, excessive $\mathrm{Cu}^{2+}$ intake is highly toxic to human health, which can result in liver damage and other neurodegenerative diseases such as Alzheimer's, Parkinson's, Wilson's and Menkes diseases [5-8]. The highest $\mathrm{Cu}^{2+}$ level in drinking water is $1.3 \mathrm{ppm}(\sim 20 \mu \mathrm{M})$ according to the U.S. Environmental Protection Agency (EPA) [9-10]. In addition, along with the widespread use of copper in industry and agriculture, $\mathrm{Cu}^{2+}$ has been a serious environmental pollutant [11]. In view of the current situation above, realistic methods with high sensitivity and selectivity for the detection of $\mathrm{Cu}^{2+}$ in environmental and organisms at cellular level are crucial.

Luminescence resonance energy transfer (LRET) biosensors, which generally are composed of an acceptor and a donor fluorophore, have been used for biosensing [12], bioimaging [13], bioassay [14], photodynamic therapy [15] and drug delivery [16]. Among those LRET sensors, lanthanide-doped upconversion nanoparticles (UCNPs) have emerged as alternatives over conventional down-shifting fluorescence probes (organic dyes, quantum dots, etc.) [17-22]. Rare-earth doped upconversion 
nanomaterials can convert long-wavelength near-infrared (NIR) light to short-wavelength UV or visible light $[23,24]$ with intriguing advantages, such as a large anti-Stokes shift, a narrow emission band, lower toxicity, no photobleaching [25], reinforced light penetration depth in tissue [26] and no autofluorescence (noise) from biosamples [27], which make upconversion nanomaterials particularly useful for sensing and bioimaging in vivo. Various nanoprobes containing upconversion nanomaterials and organic chromophores were proposed for biosensing as well as detection of special ions [28-35], small molecules [36,37], radical [38], viruses [39], amino acid [40], protein [41], DNA [42] and pH [43] based on the LRET process. Generally, upconversion nanomaterials serve as the energy donors while the organic chromophores as energy acceptors. Additionally, special interest has been paid to lanthanide ion photoluminescence [44-45].

However, most of these upconversion nanomaterials are synthesized in organic solvents or at high temperature [46] so that obtained nanocrystals are hydrophobic and difficult to dissolve in water. The direct use of these nanocrystals for biological applications is limited owing to the low solubility in aqueous solution and lack of functional chemical groups or appropriate sites for attachment of biomolecules. Thus, further surface modification of these nanocrystals is much required. More often than not, silica-coated core-shell structures are considered to be an ideal method for the modification of the upconversion nanocrystal surface because of the facile grafted other functional groups and good solubility in water $[47,48]$.

In the present study, a new $\mathrm{Cu}^{2+}$-responsive upconversion luminescence (UCL) nanoprobe was fabricated by loading meso-tetra(4-sulfonatophenyl)porphine dihydrochlorid (TSPP) [49-51] into a layer of ultrathin silica encapsulated upconversion $\quad \beta-\mathrm{NaYF}_{4}: \mathrm{Yb}, \mathrm{Er}, \mathrm{Gd} \quad$ nanorods, denoted as $\beta-\mathrm{NaYF}_{4}: \mathrm{Yb}, \mathrm{Er}, \mathrm{Gd} @ \mathrm{SiO}_{2}-\mathrm{TSPP} . \quad$ In this LRET nanoprobe, $\beta-\mathrm{NaYF}_{4}: \mathrm{Yb}, \mathrm{Er}, \mathrm{Gd}$ nanorods worked as the energy donor, ultrathin silica shell as spacer, and $\mathrm{Cu}^{2+}$-responsive TSPP as the acceptor. In the presence of $\mathrm{Cu}^{2+}$, green UCL emission decreased concomitantly, while the red UCL emission only changed a little, which was used as the reference. The proposed $\beta-\mathrm{NaYF}_{4}: \mathrm{Yb}, \mathrm{Er}, \mathrm{Gd} @ \mathrm{SiO}_{2}-\mathrm{TSPP}$ was a UCL 
turn-off nanoprobe for $\mathrm{Cu}^{2+}$.

\section{Experimental Section}

\subsection{Chemicals and materials}

$$
\mathrm{GdCl}_{3} \cdot 6 \mathrm{H}_{2} \mathrm{O} \quad(99.99 \%), \quad \mathrm{YCl}_{3} \cdot 6 \mathrm{H}_{2} \mathrm{O} \quad(99.99 \%), \quad \mathrm{YbCl}_{3} \cdot 6 \mathrm{H}_{2} \mathrm{O} \quad(99.99 \%),
$$
$\mathrm{ErCl}_{3} \bullet 6 \mathrm{H}_{2} \mathrm{O}(99.9 \%)$ were purchased from Energy Chemical. TSPP ( $\left.\geqslant 95.0 \%\right)$, igepal CO-520, (3-Aminopropyl)triethoxysilane (APTES, 97\%) and tetraethyl orthosilicate (TEOS, 99.999\%) were purchased from Aladdin. Tryptophan (Trp), arginine (Arg), asparticacid (Asp), valine(Val), leucine (Leu), tyrosine (Tyr), lysine (Lys), cysteine (Cys), glutathione (GSH), bovine serum albumin (BSA) and ovalbumin (OVA) were purchased from Sigma-Aldrich Chemical Co. (St. Louis, MO, USA). NaOH (98+\%), $\mathrm{NH}_{4} \mathrm{~F}(98+\%)$, oleic acid $(90 \%)$ and other reagents of analytical reagent grade were all obtained from commercial sources and used as starting materials without further purification. All ultrapure water was prepared with Mill-Q water (Millipore, 18.2 $\mathrm{M} \Omega . \mathrm{cm}$ resistivity) and used throughout the experiment.

\subsection{Apparatus}

The morphology of the samples was characterized with transmission electron microscopy (TEM) on a JEM 2100 (JEOL, Japan) electron microscope. These as-prepared samples were dispersed in cyclohexane or water and dropped on the surface of a copper grid for TEM test. Elemental analyses were carried out on an energy-dispersive X-ray analysis spectrometer (EDXA). Fourier transform infrared (FT-IR) spectra $\left(4000-500 \mathrm{~cm}^{-1}\right)$ in $\mathrm{KBr}$ were recorded on a spectrometer (Nicolet-5700, American). UV-vis absorption spectra were obtained on a Cary 60 spectrophotometer (Agilent Technologies). A Mettler-Toledo Delta 320 pH meter was used to measure $\mathrm{pH}$ values. UCL measurements were carried out on a Hitachi-F4600 fluorescence spectrometer (Tokyo, Japan) under the excitation of a $980 \mathrm{~nm}$ laser. The crystalline phases of the samples were characterized by an X-ray diffractometer (XRD, M21X, MAC Science Ltd., Japan) with $\mathrm{Cu} \mathrm{K \alpha}$ irradiation source and a scanning 
speed of $2^{\circ} / \mathrm{min}$ in the $2 \theta$ range of $20-80^{\circ}$.

\subsection{Synthesis of OA-Capped $\beta$-NaYF $: Y b, E r, G d(18,2,60$ mol\%) nanorods.}

The upconversion $\beta-\mathrm{NaYF}_{4}: \mathrm{Yb}, \mathrm{Er}, \mathrm{Gd}(18,2,60 \mathrm{~mol} \%)$ nanorods with high monodispersity were synthesized by a rational hydrothermal method using oleic acid as a stabilizing agent [46]. Nanorods rather than nanoparticles were chosen because of their relatively simpler synthesis method, more intense luminescence and upconversion efficiency than nanoparticles $[46,47,52,53]$. In a typical procedure for the synthesis of lanthanide-doped $\beta-\mathrm{NaYF}_{4}: \mathrm{Yb}$,Er,Gd nanorods, $3 \mathrm{~mL} \mathrm{NaOH}$ solution $(0.2 \mathrm{~g} / \mathrm{mL})$ was mixed with $20 \mathrm{~mL}$ oleic acid in ethanol $(1: 1 \mathrm{v} / \mathrm{v})$ under stirring. To the resulting mixture were added $4 \mathrm{~mL}$ of $\mathrm{RECl}_{3}(0.2 \mathrm{M}, \mathrm{RE}=\mathrm{Y}, \mathrm{Yb}, \mathrm{Er}$ and $\mathrm{Gd})$ and 2 $\mathrm{mL}$ of $\mathrm{NH}_{4} \mathrm{~F}(2 \mathrm{M})$. The solution was then transferred into a $50 \mathrm{~mL}$ Teflon-lined autoclave and heated at $200{ }^{\circ} \mathrm{C}$ for $2 \mathrm{~h}$. The obtained nanorods were collected by centrifugation, washed with ultrapure water and ethanol several times, redispersed in cyclohexane in the end.

\subsection{Synthesis of $\beta-\mathrm{NaYF}_{4}: \mathrm{Yb}, \mathrm{Er}, \mathrm{Gd} @ \mathrm{SiO}_{2}-\mathrm{NH}_{2}$ nanorods.}

The $\beta-\mathrm{NaYF}_{4}: \mathrm{Yb}, \mathrm{Er}, \mathrm{Gd} @ \mathrm{SiO}_{2}-\mathrm{NH}_{2}$ nanorods were synthesized through a water-in-oil reverse microemulsion strategy [54]. $9 \mathrm{~mL}$ of the as-prepared $\beta-\mathrm{NaYF}_{4}: \mathrm{Yb}, \mathrm{Er}, \mathrm{Gd}$ solution dispersing in cyclohexane was added into a mixture solution containing $1 \mathrm{~mL}$ Igepal CO-520 and $20 \mathrm{~mL}$ cyclohexane. After stirring for 3 h, $140 \mu \mathrm{L} \mathrm{NH} \cdot \mathrm{H}_{2} \mathrm{O}(30 \%)$ was added and the mixture was stirred for another $2 \mathrm{~h}$. Then, $1 \mathrm{~mL}$ TEOS solution in cyclohexane $(1: 4 \mathrm{v} / \mathrm{v})$ was introduced into the system within $1 \mathrm{~h}$. The mixture was hermetically stirred for $36 \mathrm{~h}$. To graft amino-groups, 50 $\mu \mathrm{L}$ APTES was added into the mixture and stirred for another $5 \mathrm{~h}$. Then $30 \mathrm{~mL}$ hexane was added to precipitate the product which was collected by centrifugation. The as-prepared nanorods were dispersed in ethanol under ultrasonic treatment, precipitated with excess hexane, and collected by centrifugation. This procedure was repeated for three times to remove excess Igepal CO-520. The as-obtained nanorods were finally dispersed in $20 \mathrm{~mL}$ ultrapure water. 


\subsection{Assembly of TSPP on $\beta-\mathrm{NaYF}_{4}: \mathrm{Yb}, \mathrm{Er}, \mathrm{Gd} @ \mathrm{SiO}_{2}-\mathrm{NH}_{2}$ nanorods.}

$1 \mathrm{~mL}$ TSPP solution $(1 \mathrm{mM})$ in water was added dropwise into $9 \mathrm{~mL}$ $\beta-\mathrm{NaYF}_{4}: \mathrm{Yb}, \mathrm{Er}, \mathrm{Gd} @ \mathrm{SiO}_{2}$ solution $(1 \mathrm{mg} / \mathrm{mL})$. After $10 \mathrm{~min}$ of ultrasonication, the mixture solution was then stirred overnight. Redundant TSPP was removed by centrifugation. The precipitate was washed several times with water and ethanol by a repetitive dispersion/precipitation cycle. The as-obtained hybrid materials $\left(\beta-\mathrm{NaYF}_{4}: \mathrm{Yb}, \mathrm{Er}, \mathrm{Gd} @ \mathrm{SiO}_{2}-\mathrm{TSPP}\right)$ were dispersed in water by a brief sonication to form a homogeneous solution and stored at $4{ }^{\circ} \mathrm{C}$.

\subsection{Analysis of $\mathrm{Cu}^{2+}$ in the HeLa cell lysate.}

The $\beta-\mathrm{NaYF}_{4}$ :Yb,Er,Gd@SiO 2 -TSPP $(1 \mathrm{mg} / \mathrm{mL}), \mathrm{Cu}^{2+}(15,30,45,60,75 \mu \mathrm{M})$ were incubated with HeLa cell lysate $(100,000$ cells $/ \mathrm{mL})$ in the $0.05 \mathrm{M}$ Tris- $\mathrm{HCl}$ solution $(\mathrm{pH}=7.4)$ with a total volume of $100 \mu \mathrm{L}$. After incubation for $10 \mathrm{~min}$, the mixture solutions were ready for measurement.

\section{Results and discussion}

\subsection{Characterization of $\beta-\mathrm{NaYF}_{4}: \mathrm{Yb}, \mathrm{Er}, \mathrm{Gd} @ \mathrm{SiO}_{2}-\mathrm{TSPP}$ Upconversion Nanocomposites.}

The upconversion nanorods were characterized by transmission electron microscopy (TEM), X-ray powder diffraction (XRD), energy-dispersive X-ray analysis (EDXA), and Fourier transform infrared spectroscopy (FT-IR).

The TEM image of Fig. 1A shows that the $\beta-\mathrm{NaYF}_{4}: \mathrm{Yb}, \mathrm{Er}, \mathrm{Gd}$ nanorods were well-dispersed and not aggregated with an average diameter of $17 \mathrm{~nm}$ and a mean length of $109 \mathrm{~nm}$. The inset in Fig. 1A shows that the nanorods are uniformly encapsulated with a thin layer of silica at a thickness of $\sim 5 \mathrm{~nm}$. The as-prepared $\beta-\mathrm{NaYF}_{4}: \mathrm{Yb}, \mathrm{Er}, \mathrm{Gd}$ nanorods are pure hexagonal phase characterized by XRD pattern of Fig. 1C (JPCDS No. 16-0334). The immobilization of TSPP on the surface of the as-prepared $\beta-\mathrm{NaYF}_{4}: \mathrm{Yb}, \mathrm{Er}, \mathrm{Gd} @ \mathrm{SiO}_{2}-\mathrm{TSPP}$ was confirmed by EDXA (Fig. 1E) in which elements $\mathrm{S}$ and $\mathrm{N}$ are characterized, while the EDXA of $\beta-\mathrm{NaYF}_{4}: \mathrm{Yb}, \mathrm{Er}, \mathrm{Gd} @ \mathrm{SiO}_{2}$ nanorods shows no S and N (Fig. 1D). 
Fig. 1B displays the Fourier-transform infrared (FT-IR) spectra of $\beta-\mathrm{NaYF}_{4}: \mathrm{Yb}, \mathrm{Er}, \mathrm{Gd}, \quad \quad \quad \mathrm{N}_{\mathrm{NaYF}}: \mathrm{Yb}, \mathrm{Er}, \mathrm{Gd} @ \mathrm{SiO}_{2}, \quad \mathrm{TSPP} \quad$ and $\beta-\mathrm{NaYF}_{4}: \mathrm{Yb}, \mathrm{Er}, \mathrm{Gd} @ \mathrm{SiO}_{2}-\mathrm{TSPP}$. For $\beta-\mathrm{NaYF}_{4}: \mathrm{Yb}, \mathrm{Er}, \mathrm{Gd}$, the peaks at 2925 and 2855 $\mathrm{cm}^{-1}$ are assigned to the asymmetric and symmetric stretch vibrations of methylene $\left(-\mathrm{CH}_{2}-\right)$ in the long alkyl chain of OA. The band at $1553 \mathrm{~cm}^{-1}$ is attributed to carbanyl group $\left(-\mathrm{C}=\mathrm{O}^{-}\right)$. These results indicate that $\mathrm{OA}$ was coated on the surface of the $\beta-\mathrm{NaYF}_{4}: \mathrm{Yb}, \mathrm{Er}, \mathrm{Gd}$ nanorods. As for $\beta-\mathrm{NaYF}_{4}: \mathrm{Yb}, \mathrm{Er}, \mathrm{Gd} @ \mathrm{SiO}_{2}$, the strong and broad absorption band at $1046 \mathrm{~cm}^{-1}$ is attributed to $\mathrm{Si}-\mathrm{O}-\mathrm{Si}$ asymmetric stretching vibration, which suggests the formation of $\beta-\mathrm{NaYF}_{4}: \mathrm{Yb}, \mathrm{Er}, \mathrm{Gd} @ \mathrm{SiO}_{2}$. At the same time, FT-IR spectra show characteristic vibration bands at $1640 \mathrm{~cm}^{-1}$ for amine groups, and bands at 739 and $632 \mathrm{~cm}^{-1}$ for TSPP on the surface of silica shell. The FT-IR data indicate the successful assembly of the complex TSPP on the surface of the as-prepared upconversion $\quad \beta-\mathrm{NaYF}_{4}: \mathrm{Yb}, \mathrm{Er}, \mathrm{Gd} @ \mathrm{SiO}_{2}$ nanorods through electrostatic attraction.

\subsection{The UCL detecting of $\mathrm{Cu}^{2+}$.}

The detection of $\mathrm{Cu}^{2+}$ relies on a LRET process between the $\beta-\mathrm{NaYF}_{4}: \mathrm{Yb}, \mathrm{Er}, \mathrm{Gd}$ nanorods working as the energy donor and the $\mathrm{Cu}^{2+}$-responsive TSPP working as the acceptor (Scheme 1). Upon excitation of $980 \mathrm{~nm}$ laser, the $\beta-\mathrm{NaYF}_{4}: \mathrm{Yb}, \mathrm{Er}, \mathrm{Gd}$ nanorods emit intense upconversion emission at $521 \mathrm{~nm}, 545 \mathrm{~nm}$ and $659 \mathrm{~nm}$ (Fig. 2, curve a), which can be assigned to ${ }^{2} \mathrm{H}_{11 / 2}-{ }^{4} \mathrm{I}_{15 / 2},{ }^{4} \mathrm{~S}_{3 / 2}-{ }^{4} \mathrm{I}_{15 / 2},{ }^{4} \mathrm{~F}_{9 / 2}-{ }^{4} \mathrm{I}_{15 / 2}$ transitions of $\mathrm{Er}^{3+}$, respectively [54]. From the UV-vis absorption spectrum of $\beta-\mathrm{NaYF}_{4}: \mathrm{Yb}, \mathrm{Er}, \mathrm{Gd} @ \mathrm{SiO}_{2}-\mathrm{TSPP}$ in the absence and presence of $\mathrm{Cu}^{2+}$ (Fig. 2, curves $\mathrm{b}$ and c), one can notice that the addition of $\mathrm{Cu}^{2+}$ results in a significant red shift of the maximum absorption of TSPP from 515 to $545 \mathrm{~nm}$, due to the formation of $\mathrm{TSPP}-\mathrm{Cu}^{2+}$ complex. As the maximum absorption at $545 \mathrm{~nm}$ is overlapped with the upconversion emission at $545 \mathrm{~nm}$ of the $\beta-\mathrm{NaYF}_{4}: \mathrm{Yb}, \mathrm{Er}, \mathrm{Gd} @ \mathrm{SiO}_{2}$ nanorods, a LRET can be happened between the $\beta-\mathrm{NaYF}_{4}: \mathrm{Yb}, \mathrm{Er}, \mathrm{Gd} @ \mathrm{SiO}_{2}$ nanorods and the TSPP-Cu ${ }^{2+}$ complex, resulting in a decrease in the UCL at $545 \mathrm{~nm}$ (Fig. 2, curve d). 
While in the absence of $\mathrm{Cu}^{2+}$, the maximum absorption of $\beta-\mathrm{NaYF}_{4}: \mathrm{Yb}, \mathrm{Er}, \mathrm{Gd} @ \mathrm{SiO}_{2}-\mathrm{TSPP}$ (which is actually the absorption of TSPP) is around $515 \mathrm{~nm}$, the LRET is weak. As TSPP- $\mathrm{Cu}^{2+}$ complex has no absorption around $659 \mathrm{~nm}$ (Fig. 2, curve c), the addition of $\mathrm{Cu}^{2+}$ induces little change in the UCL at $659 \mathrm{~nm}$ (Fig. 2 , curves $d$ and e).

Comparing the UCL intensity of $\beta-\mathrm{NaYF}_{4}: \mathrm{Yb}, \mathrm{Er}, \mathrm{Gd} @ \mathrm{SiO}_{2}$ (Fig. 2, curve a) with that of $\beta-\mathrm{NaYF}_{4}: \mathrm{Yb}, \mathrm{Er}, \mathrm{Gd} @ \mathrm{SiO}_{2}-\mathrm{TSPP}$ (Fig. 2, curve e), one can see that the immobilization of TSPP results in a little decrease in the UCL intensity at $545 \mathrm{~nm}$, the $\mathrm{U}_{545} / \mathrm{U}_{659}$ is down from 1.22 to 0.98 .

One may wonder if there is LRET between the $\beta-\mathrm{NaYF}_{4}: \mathrm{Yb}, \mathrm{Er}, \mathrm{Gd} @ \mathrm{SiO}_{2}$ and $\mathrm{Cu}^{2+}$ because $\mathrm{Cu}^{2+}$ also portrays a broad absorbance spectrum. The upconversion luminescence of the $\beta-\mathrm{NaYF}_{4}: \mathrm{Yb}, \mathrm{Er}, \mathrm{Gd} @ \mathrm{SiO}_{2}$ nanorods (without loading of TSPP) was measured in the presence of $\mathrm{Cu}^{2+}$ (Fig. 2, curve f). The addition of $0.2 \mathrm{mM} \mathrm{Cu}^{2+}$ results in an insignificant decrease in the UCL of less than $0.8 \%$ (Fig.2, curves a and f), indicating that the LRET between $\beta-\mathrm{NaYF}_{4}: \mathrm{Yb}, \mathrm{Er}, \mathrm{Gd} @ \mathrm{SiO}_{2}$ and $\mathrm{Cu}^{2+}$ is ignorable.

The influence of $\mathrm{pH}$ (from 4.0 to 9.0) on the upconversion luminescence of the $\beta-\mathrm{NaYF}_{4}: \mathrm{Yb}, \mathrm{Er}, \mathrm{Gd} @ \mathrm{SiO}_{2}-\mathrm{TSPP}$ with/without $\mathrm{Cu}^{2+}$ was also investigated shown in Fig. S1. The results show that the effect of $\mathrm{pH}$ on the responses in the range of 5.0-8.0 is insignificant no matter in the presence or absence of $\mathrm{Cu}^{2+}$, indicating that this sensor is suitable for applications in physiological conditions. To make this probe feasible and biocompatible, $\mathrm{pH}=7.4$ was selected for the detection of $\mathrm{Cu}^{2+}$.

Fig. 3 shows the changes of UCL spectra upon continuous addition of $\mathrm{Cu}^{2+}$, the UCL intensity at $545 \mathrm{~nm}$ significantly decreases while the UCL intensity at $659 \mathrm{~nm}$ just changes a little. As the UCL intensity at $659 \mathrm{~nm}$ is independent on the $\mathrm{Cu}^{2+}$ concentration while the UCL intensity at $545 \mathrm{~nm}$ is dependent on the $\mathrm{Cu}^{2+}$ concentration, the UCL intensity at $659 \mathrm{~nm}$ can be therefore used as the reference. $\mathrm{Cu}^{2+}$ can be quantified based on the ratio of UCL intensity at $545 \mathrm{~nm}$ to that at $659 \mathrm{~nm}$ $\left(\mathrm{U}_{545} / \mathrm{U}_{659}\right)$. The changes $(\Delta \mathrm{R})$ of the $\mathrm{UCL}$ intensity ratio relative to the blank was used to quantify $\mathrm{Cu}^{2+}$ :

$$
\Delta \mathrm{R}=\left(\mathrm{U}_{545} / \mathrm{U}_{659}\right)_{0^{-}}\left(\mathrm{U}_{545} / \mathrm{U}_{659}\right)
$$


Where $\left(\mathrm{U}_{545} / \mathrm{U}_{659}\right)_{0}$ is the blank response without $\mathrm{Cu}^{2+}$.

As shown in Fig. 4 the changes of UCL intensity ratio are linear related to the $\mathrm{Cu}^{2+}$ concentration in $0-0.16 \mathrm{mM}$. The limit of detection (LOD) given by the three times noise was calculated to be $2.16 \mu \mathrm{M}$ with a noise of 0.005 calculated from blank measurements $(\mathrm{n}=10)$ (Fig. 4, inset).

\subsection{Selectivity.}

For an excellent detection system, high selectivity is of great importance. To validate the selectivity of the $\beta-\mathrm{NaYF}_{4}: \mathrm{Yb}, \mathrm{Er}, \mathrm{Gd} @ \mathrm{SiO}_{2}-\mathrm{TSPP}$ nanoprobe, the responses to some common metal ions in the presence of $0.2 \mathrm{mM} \mathrm{Cu}^{2+}$ were investigated, including $\mathrm{Na}^{+}, \mathrm{K}^{+}, \mathrm{Ca}^{2+}, \mathrm{Mg}^{2+}, \mathrm{Fe}^{3+}, \mathrm{Fe}^{2+}, \mathrm{Ni}^{2+}, \mathrm{Co}^{2+}, \mathrm{Mn}^{2+}, \mathrm{Cd}^{2+}, \mathrm{Cr}^{3+}$, $\mathrm{Pb}^{2+}, \mathrm{Hg}^{2+}$, and $\mathrm{Ag}^{+}\left(\mathrm{Na}^{+}, 10 \mathrm{mM} ; \mathrm{K}^{+}, 5.0 \mathrm{mM} ; \mathrm{Ca}^{2+}, 20 \mathrm{mM} ; \mathrm{Mg}^{2+}, 20 \mathrm{mM} ; \mathrm{Fe}^{3+}, 5.0\right.$ $\mathrm{mM}$; other metal ions, $1 \mathrm{mM}$ ). As shown in Fig. 5A, the proposed probe shows a high selectivity toward $\mathrm{Cu}^{2+}$. As high as 100 times some coexisting interferents result in only upto $2.5 \%$ deviation in the responses. The high selectivity is due to the high thermodynamic affinity of the $\mathrm{N}$, O-chelate ligands to $\mathrm{Cu}^{2+}$ and fast metal-to-ligand binding kinetics [5]. As shown in Fig. 5B, the addition of metal ions except $\mathrm{Cu}^{2+}$ results in insignificant changes in the upconversion luminescence spectra, only $\mathrm{Cu}^{2+}$ can induce a significant decrease in the UCL intensity at $545 \mathrm{~nm}$. From the UV-vis absorption spectra in Fig. 6, one also can see the addition of the investigated ions only $\mathrm{Cu}^{2+}$ results in red shift of the maximum absorption at $515 \mathrm{~nm}$.

Considering the application in the analysis of $\mathrm{Cu}^{2+}$ in organisms, selectivity was investigated against those biological compounds that existing in organisms, including some natural amino acids: tryptophan (Trp), arginine (Arg), asparticacid (Asp), valine(Val), leucine (Leu), tyrosine (Tyr), lysine (Lys), cysteine (Cys), and peptides: glutathione (GSH), as well as proteins: bovine serum albumin (BSA) and ovalbumin (OVA). As shown in Fig.5A, coexisting of $0.5 \mathrm{mM}$ above amino acids , $0.5 \mathrm{mM}$ peptides and $2 \mathrm{mg} / \mathrm{mL}$ proteins with $0.2 \mathrm{mM} \mathrm{Cu}^{2+}$ results in only upto $2.1 \%$ deviations in the responses. 


\subsection{Determination of $\mathrm{Cu}^{2+}$ in the HeLa cell lysates.}

The proposed method was compared with some published works in terms of the sensitivity and linear range, with results shown in Table 1. The proposed method exhibited a comparable sensitivity with the published works. The proposed nanoprobe has a quick response of less than $10 \mathrm{~s}$ upon the addition of $\mathrm{Cu}^{2+}$. In addition, the nanocomposite has good water solubility and biocompatibility, which makes the nanoprobe possible to be applied in biological fields.

The practical application of this nanoprobe was evaluated through the determination of $\mathrm{Cu}^{2+}$ spiked in HeLa cell lysates. The recovery experiment was summarized in Table 2, giving recoveries ranging from $98 \%$ to $102 \%$ and the RSD below 5.0\%. These results show a good agreement with those for $\mathrm{Cu}^{2+}$ detection in buffer solutions, further confirming the sensor is promising for the detection of $\mathrm{Cu}^{2+}$ in real biological samples.

\section{Conclusion}

Dye-assembled nanocomposites $\quad \beta-\mathrm{NaYF}_{4}: \mathrm{Yb}, \mathrm{Er}, \mathrm{Gd} @ \mathrm{SiO}_{2}-\mathrm{TSPP} \quad$ were developed for rapid upconversion luminescence sensing of $\mathrm{Cu}^{2+}$ based on luminescence resonance energy transfer with the $\beta-\mathrm{NaYF}_{4}: \mathrm{Yb}, \mathrm{Er}, \mathrm{Gd}$ nanorods as the energy donor, and the $\mathrm{Cu}^{2+}$-responsive TSPP as the energy acceptor. The formation of TSPP- $\mathrm{Cu}^{2+}$ complex resulted in the quench of nanocomposite emission at $545 \mathrm{~nm}$, and $\mathrm{Cu}^{2+}$ was detected based on the decrease in emission intensity at $545 \mathrm{~nm}$. A linear response was obtained in the range of $5 \mu \mathrm{M}$ to $0.16 \mathrm{mM}$ with a LOD of $2.16 \mu \mathrm{M}$. The proposed probe shows a high selectivity. As the prepared $\beta-\mathrm{NaYF}_{4}: \mathrm{Yb}, \mathrm{Er}, \mathrm{Gd} @ \mathrm{SiO}_{2}-\mathrm{TSPP}$ can be well-dispersed in aqueous and is based on upconversion luminescence, the proposed probe can be applied in assay of $\mathrm{Cu}^{2+}$ in biological systems. The analysis of $\mathrm{Cu}^{2+}$ in biological systems was evaluated by the determination of $\mathrm{Cu}^{2+}$ spiked in Hela cell lysates with recoveries ranging from $98 \%$ to $102 \%$ and RSD below $5.0 \%$.

Acknowlegements: We gratefully acknowledge the National Science Foundation of 
China (grants 21235002 and 21175038) for financial support.

\section{References}

[1] J.L. Yao, K. Zhang, H.J. Zhu, F. Ma, M.T. Sun, H. Yu, J. Sun, S.H. Wang, Efficient ratiometric fluorescence probe based on dual-emission quantum dots hybrid for on-site determination of copper ions, Anal. Chem. 85 (2013) 6461-6468.

[2] X.J. Liu, N. Zhang, T. Bing, D.H. Shangguan, Carbon dots based dual-emission silica nanoparticles as a ratiometric nanosensor for $\mathrm{Cu}^{2+}$, Anal. Chem. 86 (2014) 2289-2296.

[3] S. Sarkar, M. Chatti, V.N.K.B. Adusumalli, V. Mahalingam, Highly selective and sensitive detection of $\mathrm{Cu}^{2+}$ ions using $\mathrm{Ce}(\mathrm{III}) / \mathrm{Tb}$ (III)-doped $\mathrm{SrF}_{2}$ nanocrystals as fluorescent probe, Appl. Mater. Interfaces. 7 (2015) 25702-25708.

[4] Y. Choi, Y. Park, T. Kang, L.P. Lee, Selective and sensitive detection of metal ions by plasmonic resonance energy transfer-based nanospectroscopy, Nature Nanotechnology. 4 (2009) 742-746.

[5] J. Zhang, B. Li, L.M. Zhang, H. Jiang, An optical sensor for $\mathrm{Cu}(\mathrm{II})$ detection with upconverting luminescent nanoparticles as an excitation source, Chem. Commun. 48 (2012) $4860-4862$.

[6] P.J.J. Huang, J.W. Liu, An ultrasensitive light-up $\mathrm{Cu}^{2+}$ biosensor using a new DNAzyme cleaving a phosphorothioate-modified substrate, Anal. Chem. 88 (2016) 3341-3347.

[7] Y.Q. Lin, C. Wang, L.B. Li, H. Wang, K.Y. Liu, K.Q. Wang, B. Li, Tunable fluorescent silica-coated carbon dots: a synergistic effect for enhancing the fluorescence sensing of extracellular $\mathrm{Cu}^{2+}$ in rat brain, Appl. Mater. Interfaces. 7 (2015) 27262-27270.

[8] C.X. Li, J.L. Liu, S. Alonso, F.Y. Li, Y. Zhang, Upconversion nanoparticles for sensitive and in-depth detection of $\mathrm{Cu}^{2+}$ ions, Nanoscale. 4 (2012) 6065-6071.

[9] C.H. Zong, K.L. Ai, G. Zhang, H.W. Li, L.H. Lu, Dual-emission fluorescent silica nanoparticle-based probe for ultrasensitive detection of $\mathrm{Cu}$, Anal. Chem. 83 (2011) 3126-3132.

[10] X.M. Jiang, G.W. Meng, A rhodamine-based sensing probe excited by upconversion $\mathrm{NaYF}_{4}: \mathrm{Yb}^{3+} / \mathrm{Er}^{3+}$ nanoparticles: the realization of simple $\mathrm{Cu}(\mathrm{II})$ detection with high 
sensitivity and unique selectivity, Journal of Luminescence. 135 (2013) 227-231.

[11] P.G. Georgopoulos, A. Roy, M.J. Yonone-Lioy, R.E. Opiekun, P.J. Lioy, Environmental copper: its dynamics and human exposure issues, Toxicol. Environ. Health, Part B. 4 (2001) $341-394$.

[12] S.J. Liu, L.L. Zhang, T.S. Yang, H.R. Yang, K.Y. Zhang, X. Zhao, W. Lv, Q. Yu, X.L. Zhang, Q. Zhao, X.M. Liu, W. Huang, Development of upconversion luminescent probe for ratiometric sensing and bioimaging of hydrogen sulfide, Appl. Mater. Interfaces. 6 (2014) $11013-11017$

[13] O.S. Kwon, H.S. Song, J. Conde, H. Kim, N. Artzi, J.H. Kim, Dual-color emissive upconversion nanocapsules for differential cancer bioimaging in vivo, ACS Nano. 10 (2016) $1512-1521$

[14] J. Zhou, Q. Liu, W. Feng, Y. Sun, F.Y. Li, Upconversion luminescent materials: advances and applications, Chem. Rev. 115 (2015) 395-465.

[15] Q.F. Xiao, X.P. Zheng, W.B. Bu, W.Q. Ge, S.J. Zhang, F. Chen, H.Y. Xing, Q.G. Ren, W.P. Fan, K.L. Zhao, Y.Q. Hua, J.L. Shi, A core/satellite multifunctional nanotheranostic for in vivo imaging and tumor eradication by radiation/photothermal synergistic therapy, J. Am. Chem. Soc. 135 (2013) 13041-13048.

[16] K. Li, Q.Q. Su, W. Yuan, B. Tian, B. Shen, Y.H. Li, W. Feng, F.Y. Li, Ratiometric monitoring of intracellular drug release by an upconversion drug delivery nanosystem, Appl. Mater. Interfaces. 7 (2015) 12278-12286.

[17] J. Yuan, Y. Cen, X.J. Kong, S. Wu, C.L.W. Liu, R.Q. Yu, X. Chu, $\mathrm{MnO}_{2}$-nanosheet-modified upconversion nanosystem for sensitive turn-on fluorescence detection of $\mathrm{H}_{2} \mathrm{O}_{2}$ and glucose in blood, Appl. Mater. Interfaces. 7 (2015) 10548-10555.

[18] R.R. Deng, X.J. Xie, M. Vendrell, Y.T. Chang, X.G. Liu, Intracellular glutathione detection using $\mathrm{MnO}_{2}$-nanosheet-modified upconversion nanoparticles, J. Am. Chem. Soc. 133 (2011) 20168-20171.

[19] Y.X. Ma, S. Huang, M.L. Deng, L.Y. Wang, White upconversion luminescence nanocrystals for the simultaneous and selective detection of 2,4,6-trinitrotoluene and 2,4,6-trinitrophenol, Appl. Mater. Interfaces. 6 (2014) 7790-7796.

[20] D. Wang, C. Chen, X.B. Ke, N. Kang, Y.Q. Shen, Y.L. Liu, X. Zhou, H.J. Wang, C.Q. Chen, 
L. Ren, Bioinspired near-infrared-excited sensing platform for in vitro antioxidant capacity assay based on upconversion nanoparticles and a dopamine-melanin hybrid system, Appl. Mater. Interfaces. 7 (2015) 3030-3040.

[21] M.Y. He, Z. Li, Y.Y. Ge, Z.H. Liu, Portable upconversion nanoparticles-based paper device for field testing of drug abuse, Anal. Chem. 88 (2016) 1530-1534.

[22] C. Ma, T. Bian, S. Yang, C.H. Liu, T.R. Zhang, J.F. Yang, Y.H. Li, J.S. Li, R.H. Yang, W.H. Tan, Fabrication of versatile cyclodextrin-functionalized upconversion luminescence nanoplatform for biomedical imaging, Anal. Chem. 86 (2014) 6508-6515.

[23] F. Auzel, Upconversion and anti-stokes processes with $\mathrm{f}$ and d ions in solids, Chem. Rev. 104 (2004) 139-173.

[24] J.F. Suyver, A. Aebischer, D. Biner, P. Gerner, J. Grimm, S. Heer, K.W. Krämer, C. Reinhard, H.U. Güdel, Novel materials doped with trivalent lanthanides and transition metal ions showing near-infrared to visible photon upconversion, Opt. Mater. 27 (2005) 1111-1130.

[25] Y. Park, J.H. Kim, K.T. Lee, K.S. Jeon, H.B. Na, J.H. Yu, H.M. Kim, N. Lee, S.H. Choi, S.B. Aik, Nonblinking and nonbleaching upconverting nanoparticles as an optical imaging nanoprobe and T1 magnetic resonance imaging contrast agent, Adv. Mater. 21 (2009) $4467-4471$.

[26] L.Q. Xiong, Z.G. Chen, Q.W. Tian, T.Y. Cao, C.J. Xu, F.Y. Li, High contrast upconversion luminescence targeted imaging in vivo using peptide-labeled nanophosphors, Anal. Chem. 81 (2009) 8687-8694.

[27] M.X. Yu, F.Y. Li, Z.G. Chen, H. Hu, C. Zhan, H. Yang, C.H. Huang, Laser scanning up-conversion luminescence microscopy for imaging cells labeled with rare-earth nanophosphors, Anal. Chem. 81 (2009) 930-935.

[28] Q. Liu, J.J. Peng, L.N. Sun, F.Y. Li, High-efficiency upconversion luminescent sensing and bioimaging of $\mathrm{Hg}(\mathrm{II})$ by chromophoric ruthenium complex-assembled nanophosphors, ACS Nano. 5 (2011) 8040-8048.

[29] J.J. Peng, W. Xu, C.L. Teoh, S.Y. Han, B. Kim, A. Samanta, J.C. Er, L. Wang, L. Yuan, X.G. Liu, Y.T. Chang, High-efficiency in vitro and in vivo detection of $\mathrm{Zn}^{2+}$ by dye assembled upconversion nanoparticles, J. Am. Chem. Soc. 137 (2015) 2336-2342.

[30] Z. Li, S.W. Lv, Y.L. Wang, S.Y. Chen, Z.H. Liu. Construction of LRET-based nanoprobe 
using upconversion nanoparticles with confined emitters and bared surface as luminophore, J. Am. Chem. Soc. 137 (2015) 3421-3427.

[31] J.L. Liu, Y. Liu, Q. Liu, C.Y. Li, L.N. Sun, F.Y. Li, Iridium(III) complex-coated nanosystem for ratiometric upconversion luminescence bioimaging of cyanide anions, J. Am. Chem. Soc. 133 (2011) 15276-15279.

[32] Y.X. Wu, X.B. Zhang, D.L. Zhang, C.C. Zhang, J.B. Li, Y. Wu, Z.L. Song, R.Q. Yu, W.H. Tan. Quench-shield ratiometric upconversion luminescence nanoplatform for biosensing, Anal. Chem. 88 (2016) 1639-1646.

[33] R.Y. Wei, Z.W. Wei, L.N. Sun, J.Z. Zhang, J.L. Liu, X.Q. Ge, L.Y. Shi, Nile red derivative-modified nanostructure for upconversion luminescence sensing and intracellular detection of $\mathrm{Fe}^{3+}$ and MR imaging, Appl. Mater. Interfaces. 8 (2016) 400-410.

[34] X.M. Zou, Y. Liu, X.J. Zhu, M. Chen, L.M. Yao, W. Feng, F.Y. Li, Nd ${ }^{3+}$-sensitized upconversion nanophosphor modified with cyanine dye for ratiometric upconversion luminescence bioimaging of hypochlorite, Nanoscale. 7 (2015) 4105-4113.

[35] Y. Liu, M. Chen, T.Y. Cao, Y. Sun, C.Y. Li, Q. Liu, T.S. Yang, L.M. Yao, W. Feng, F.Y. Li, A cyanine-modified nanosystem for in vivo upconversion luminescence bioimaging of methylmercury, J. Am. Chem. Soc. 135 (2013) 9869-9876.

[36] D.E. Achatz, R.J. Meier, L.H. Fischer, O.S. Wolfbeis, Luminescent sensing of oxygen using a quenchable probe and upconverting nanoparticles, Angew. Chem. Int. Ed. 50 (2011) $260-263$.

[37] J.N. Liu, Y. Liu, W.B. Bu, J.W. Bu, Y. Sun, J.L. Du, J.L. Shi, Ultrasensitive nanosensors based on upconversion nanoparticles for selective hypoxia imaging in vivo upon near-infrared excitation, J. Am. Chem. Soc. 136 (2014) 9701-9709.

[38] Z. Li, T. Liang, S.W. Lv, Q.G. Zhuang, Z.H. Liu, A rationally designed upconversion nanoprobe forin vivo detection of hydroxyl radical, J. Am. Chem. Soc. 137 (2015) $11179-11185$.

[39] M.K. Tsang, W.W. Ye, G.J. Wang, J.M. Li, M. Yang, J.H. Hao, Ultrasensitive detection of Ebola virus oligonucleotide based on upconversion nanoprobe/nanoporous membrane system, ACS Nano. 10 (2016) 598-605.

[40] L.Z. Zhao, J.J. Peng, M. Chen, Y. Liu, L.M. Yao, W. Feng, F.Y. Li, Yolk-shell upconversion 
nanocomposites for LRET sensing of cysteine/homocysteine. Appl. Mater. Interfaces. 6 (2014) 11190-11197.

[41] E.J. Jo, H. Mun, M.G. Kim, Homogeneous immunosensor based on luminescence resonance energy transfer for glycated hemoglobin detection using upconversion nanoparticles, Anal. Chem. 88 (2016) 2742-2746.

[42] J.L. Liu, J.T. Cheng, Y. Zhang, Upconversion nanoparticle based LRET system for sensitive detection of MRSA DNA sequence, Biosens. Bioelectron. 43 (2013) 252-256.

[43] L.N. Sun, H.S. Peng, M.I.J. Stich, D. Achatz, O.S. Wolfbeis, pH sensor based on upconverting luminescent lanthanide nanorods, Chem. Commun. 33 (2009) 5000-5002.

[44] E. Stathatos, P. Lianos, Highly efficient photoluminescent films made by mixing aminopropyltriethoxysilane, $\mathrm{Eu}^{3+}$ ions, and thenoyltrifluoroacetone, Appl. Phys. Lett. 90 (2007) 061110-3.

[45] E. Stathatos, P. Lianos, Enhanced photoluminescence from films made of titanium tetraisopropoxide, $\mathrm{Eu}^{3+}$ ions and thenoyltrifluoroacetone blends, Chemical Physics Letters. 417 (2006) 406-409.

[46] F. Wang, Y. Han, C.S. Lim, Y.H. Lu, J. Wang, J. Xu, H.Y. Chen, C. Zhang, M.H. Hong, X.G. Liu, Simultaneous phase and size control of upconversio nanocrystals through lanthanide doping, Nature. 463 (2010) 1061-1065.

[47] J.P. Yang, Y.H. Deng, Q.L. Wu, J. Zhou, H.F. Bao, Q. Li, F. Zhang, F.Y. Li, B. Tu, D.Y. Zhao, Mesoporous silica encapsulating upconversion luminescence rare-earth fluoride nanorods for secondary excitation, Langmuir. 26 (2010) 8850-8856.

[48] Y.H. Yang, M.Y. Gao, Preparation of fluorescent $\mathrm{SiO}_{2}$ particles with single CdTe nanocrystal cores by the reverse microemulsion method, Adv. Mater. 17 (2005) 2354-2357.

[49] K.Y. Yeon, D. Jeong, S.K. Kim, Intrinsic lifetimes of the Soret bands of the free-base tetraphenylporphine $\left(\mathrm{H}_{2} \mathrm{TPP}\right)$ and $\mathrm{Cu}(\mathrm{II}) \mathrm{TPP}$ in the condensed phase, Chem. Commun. 46 (2010) 5572-5574.

[50] L.X. Shi, B. Hernandez, M. Selke, Singlet oxygen generation from water-soluble quantum dot-organic dye nanocomposites, J. Am. Chem. Soc. 128 (2006) 6278-6279.

[51] A.D. Schwab, D.E. Smith, C.S. Rich, E.R. Young, W.F. Smith, J.C. de Paula, Porphyrin nanorods, J. Phys. Chem. B. 107 (2003) 11339-11345. 
[52] L.Y. Wang, Y.D. $\mathrm{Li}, \mathrm{Na}\left(\mathrm{Y}_{1.5} \mathrm{Na}_{0.5}\right) \mathrm{F}_{6}$ single-crystal nanorods as multicolor luminescent materials, Nano Letters. 6 (2006) 1645-1649.

[53] G.Z. Ren, S.J. Zeng, J.H. Hao, Tunable multicolor upconversion emissions and paramagnetic property of monodispersed bifunctional lanthanide-doped $\mathrm{NaGdF}_{4}$ nanorods, J. Phys. Chem. C. 115 (2011) 20141-20147.

[54] M. Wang, C.C. Mi, W.X. Wang, C.H. Liu, Y.F. Wu, Z.R. Xu, C.B. Mao, S.K. Xu. Immunolabeling and NIR-excited fluorescent imaging of $\mathrm{HeLa}$ cells by using $\mathrm{NaYF}_{4}: \mathrm{Yb}$, $\mathrm{Er}$ upconversion nanoparticles, ACS Nano. 3 (2009) 1580-1586.

[55] B.C. Yin, B.C. Ye, W.H. Tan, H. Wang, C.C. Xie, An allosteric dual-DNAzyme unimolecular probe for colorimetric detection of Copper(II), J. Am. Chem. Soc. 131 (2009) 14624-14625.

[56] P. Kaur, D. Sareen, K. Singh, Selective colorimetric sensing of $\mathrm{Cu}^{2+}$ using triazolyl monoazo derivative, Talanta. 83 (2011) 1695-1700.

[57] H.Y. Luo, X.B. Zhang, J.H. Jiang, C.Y. Li, J. Peng, G.L. Shen, R.Q. Yu, An optode sensor for $\mathrm{Cu}^{2+}$ with high selectivity based on porphyrin derivative appended with bipyridine, Analytical Sciences. 23 (2007) 551-555.

[58] P. Hashemi, M.M. Abolghasemi, K. Alizadeh, R.A. Zarjani, A calmagite immobilized agarose membrane optical sensor for selective monitoring of $\mathrm{Cu}^{2+}$, Sensors and Actuators B:Chemical. 129 (2008) 332-338

[59] M.M. Rahman, K.A. Alamry, T.S. Saleh, A.M. Asiri, Sensitive and selective $\mathrm{Cu}^{2+}$ sensor based on 4-(3-(thiophen-2-yl)-9Hcarbazol-9-yl)benzaldehyde (TPCBZ) conjugated copper-complex, Journal of Organometallic Chemistry. 817 (2016) 43-49. 


\section{Figure Captions}

Fig. 1. TEM images of $\beta-\mathrm{NaYF}_{4}: \mathrm{Yb}, \mathrm{Er}, \mathrm{Gd}(18,2,60 \mathrm{~mol} \%)$ nanorods (A) and inset is $\beta-\mathrm{NaYF}_{4}: \mathrm{Yb}, \mathrm{Er}, \mathrm{Gd} @ \mathrm{SiO}_{2} \quad$ nanorods. $\quad \mathrm{FT}-\mathrm{IR} \quad$ of $\quad \beta-\mathrm{NaYF}_{4}: \mathrm{Yb}, \mathrm{Er}, \mathrm{Gd}$, $\beta-\mathrm{NaYF}_{4}: \mathrm{Yb}, \mathrm{Er}, \mathrm{Gd} @ \mathrm{SiO}_{2}, \mathrm{TSPP}$, and $\beta-\mathrm{NaYF}_{4}: \mathrm{Yb}, \mathrm{Er}, \mathrm{Gd} @ \mathrm{SiO}_{2}-\mathrm{TSPP}$ (B). X-ray powder diffraction pattern of the as-prepared $\beta-\mathrm{NaYF}_{4}: \mathrm{Yb}, \mathrm{Er}, \mathrm{Gd}$ nanorods, showing that all peaks can be well indexed in accordance with pure hexagonal $\beta-\mathrm{NaYF}_{4}$ (JCPDS card no.16-0334) (C). The EDXA of $\beta-\mathrm{NaYF}_{4}: \mathrm{Yb}, \mathrm{Er}, \mathrm{Gd} @ \mathrm{SiO}_{2}$ (D) and $\beta-\mathrm{NaYF}_{4}: \mathrm{Yb}, \mathrm{Er}, \mathrm{Gd} @ \mathrm{SiO}_{2}-\mathrm{TSPP}(\mathrm{E})$.

Scheme 1. Schematic illustration of synthesis of the TSPP-modified upconversion $\beta-\mathrm{NaYF}_{4}: \mathrm{Yb}, \mathrm{Er}, \mathrm{Gd}$ nanorods $\left(\beta-\mathrm{NaYF}_{4}: \mathrm{Yb}, \mathrm{Er}, \mathrm{Gd} @ \mathrm{SiO}_{2}-\mathrm{TSPP}\right)$, and their LRET process towards $\mathrm{Cu}^{2+}$.

Fig. 2. The UCL spectrum of $\beta-\mathrm{NaYF}_{4}: \mathrm{Yb}, \mathrm{Er}, \mathrm{Gd} @ \mathrm{SiO}_{2}$ without (blue line, curve a) and with $0.2 \mathrm{mM} \mathrm{Cu}^{2+}$ (purple line, curve f); as well as the UCL spectrum of $\beta-\mathrm{NaYF}_{4}: \mathrm{Yb}, \mathrm{Er}, \mathrm{Gd} @ \mathrm{SiO}_{2}-\mathrm{TSPP}$ with (orange line, curve d) and without $0.2 \mathrm{mM} \mathrm{Cu}^{2+}$ (gray line, curve e). UV-vis absorption spectra of $\beta-\mathrm{NaYF}_{4}: \mathrm{Yb}, \mathrm{Er}, \mathrm{Gd} @ \mathrm{SiO}_{2}-\mathrm{TSPP}$ without (black line, curve b) and with $0.2 \mathrm{mM} \mathrm{Cu}^{2+}$ (red line, curve c).

Fig. 3. Upconversion luminescence spectra of $\beta-\mathrm{NaYF}_{4}: \mathrm{Yb}, \mathrm{Er}, \mathrm{Gd} @ \mathrm{SiO}_{2}-\mathrm{TSPP}$ in $0.05 \mathrm{M}$ Tris-HCl solution $(\mathrm{pH}=7.4)$ upon gradual addition of $\mathrm{Cu}^{2+}(0-0.4 \mathrm{mM})$.

Fig. 4. Change of UCL intensity ratio at 545 to $659 \mathrm{~nm}, \Delta \mathrm{R}=\left(\mathrm{U}_{545} / \mathrm{U}_{659}\right)_{0^{-}}\left(\mathrm{U}_{545} / \mathrm{U}_{659}\right)$ upon addition of $0-0.4 \mathrm{mM} \mathrm{Cu}^{2+}$, inset is the linear fitting in the concentration range of $0-0.16 \mathrm{mM}$.

Fig. 5. (A) The effect of coexisting ions and biological compounds on the signal $(\Delta R)$ of the ratiometric probe in the presence of $\mathrm{Cu}^{2+}$. Final concentrations: $\mathrm{Cu}^{2+}, 0.2 \mathrm{mM}$; $\mathrm{Na}^{+}, 10 \mathrm{mM} ; \mathrm{K}^{+}, 5.0 \mathrm{mM} ; \mathrm{Ca}^{2+}, 20 \mathrm{mM} ; \mathrm{Mg}^{2+}, 20 \mathrm{mM} ; \mathrm{Fe}^{3+}, 5.0 \mathrm{mM}$; other metal 
ions, $1 \mathrm{mM}$; $0.5 \mathrm{mM}$ above amino acids; $0.5 \mathrm{mM}$ peptides and $2 \mathrm{mg} / \mathrm{mL}$ proteins. $\Delta \mathrm{R}=\left(\mathrm{U}_{545} / \mathrm{U}_{659}\right)_{0^{-}}\left(\mathrm{U}_{545} / \mathrm{U}_{659}\right)$, where $\left(\mathrm{U}_{545} / \mathrm{U}_{659}\right)_{0}$ is the blank response. (B) UCL spectra of $\beta-\mathrm{NaYF}_{4}: \mathrm{Yb}, \mathrm{Er}, \mathrm{Gd} @ \mathrm{SiO}_{2}-\mathrm{TSPP}$ solutions $(1 \mathrm{mg} / \mathrm{mL})$ in the presence of different metal ions $\left(\mathrm{Cu}^{2+}, 0.2 \mathrm{mM} ; \mathrm{Na}^{+}, 10 \mathrm{mM} ; \mathrm{K}^{+}, 5.0 \mathrm{mM} ; \mathrm{Ca}^{2+}, 20 \mathrm{mM} ; \mathrm{Mg}^{2+}\right.$, $20 \mathrm{mM} ; \mathrm{Fe}^{3+}, 5.0 \mathrm{mM}$; other metal ions, $1 \mathrm{mM}$ ).

Fig. 6. Absorption spectra of TSPP after reacting with common metal ions in $0.05 \mathrm{M}$ Tris-HCl solutions $(\mathrm{pH}=7.4)\left(\mathrm{Na}^{+}, \mathrm{K}^{+}, \mathrm{Ca}^{2+}, \mathrm{Mg}^{2+}, \mathrm{Fe}^{3+}, \mathrm{Fe}^{2+}, \mathrm{Ni}^{2+}, \mathrm{Co}^{2+}, \mathrm{Mn}^{2+}, \mathrm{Cd}^{2+}\right.$, $\mathrm{Cr}^{3+}, \mathrm{Pb}^{2+}, \mathrm{Hg}^{2+}, \mathrm{Ag}^{+}$, and $\left.\mathrm{Cu}^{2+}\right)$.

Table 1. Comparison of the principles and analytical parameters of different $\mathrm{Cu}^{2+}$ probes.

Table 2. Recovery study for $\mathrm{Cu}^{2+}$ using $\beta-\mathrm{NaYF}_{4}$ : $\mathrm{Yb}, \mathrm{Er}, \mathrm{Gd} @ \mathrm{SiO}_{2}-\mathrm{TSPP}$ sensor with HeLa cell lysates. 
Table 1. Comparison of the principles and analytical parameters of different $\mathrm{Cu}^{2+}$ probes.

\begin{tabular}{|c|c|c|c|c|c|}
\hline Method & Probe & Detection mechanism & Analytical range & LOD & Reference \\
\hline UCL & $\beta-\mathrm{NaYF}_{4}: \mathrm{Yb}, \mathrm{Er}, \mathrm{Gd} @ \mathrm{SiO}_{2}-\mathrm{TSPP}$ & LRET & $5 \mu \mathrm{M}-0.16 \mathrm{mM}$ & $2.16 \mu \mathrm{M}$ & This work \\
\hline UCL & UCNPs -RB-hydrazide & FRET & $1 \mu \mathrm{M}-10 \mu \mathrm{M}$ & $1 \mu \mathrm{M}$ & {$[5]$} \\
\hline UCL & $\beta-\mathrm{NaYF}_{4}: \mathrm{Yb}^{3+} / \mathrm{Er}^{3+}: \mathrm{Rd}^{-\mathrm{NH}_{2}}$ & ET & $2 \mu \mathrm{M}-14 \mu \mathrm{M}$ & - & {$[10]$} \\
\hline Colorimetric & Allosteric Dual-DNAzyme Unimolecular & Molecular engineering & $1 \mu \mathrm{M}-1.0 \mathrm{mM}$ & $1 \mu \mathrm{M}$ & [55] \\
\hline Colorimetric & Triazolyl monoazo derivative & Stabilization of LUMO & - & $13.6 \mu \mathrm{M}$ & [56] \\
\hline Optical chemical & $\mathrm{H}_{2}$ TPPBPy optode membrane & ET & $0.2 \mathrm{nM}-10 \mu \mathrm{M}$ & $5 \mathrm{nM}$ & [57] \\
\hline Optical & Calmagite immobilized agarose membrane & Complexation reaction & $0.4-200 \mu \mathrm{g} \mathrm{l}^{-1}$ & $0.07 \mu \mathrm{g}^{-1}$ & {$[58]$} \\
\hline Electrochemical & TPCBZ/Nafion/GCE & Conjugated complex & $1.0 \mathrm{nM}-1.0 \mathrm{mM}$ & $0.84 \mathrm{nM}$ & [59] \\
\hline
\end{tabular}

Table 2. Recovery study for $\mathrm{Cu}^{2+}$ using $\beta-\mathrm{NaYF}_{4}$ : $\mathrm{Yb}, \mathrm{Er}, \mathrm{Gd} @ \mathrm{SiO}_{2}-\mathrm{TSPP}$ sensor with HeLa cell lysates.

\begin{tabular}{ccccc}
\hline Sample number & Add $(\mu \mathbf{M})$ & ${\text { Found }(\mu M)^{\mathbf{a}}}$ & ${\text { Recovery }(\%)^{\mathbf{a}}}$ & ${\text { RSD }(\%)^{\mathbf{a}}}^{\mathbf{a}}$ \\
\hline 1 & 15 & 14.85 & 99 & 5.0 \\
2 & 30 & 29.54 & 98 & 3.2 \\
3 & 45 & 45.37 & 101 & 1.2 \\
4 & 60 & 61.07 & 102 & 1.5 \\
5 & 75 & 75.86 & 101 & 2.1 \\
\hline
\end{tabular}

${ }^{a}$ the average value of three parallel determinations. 


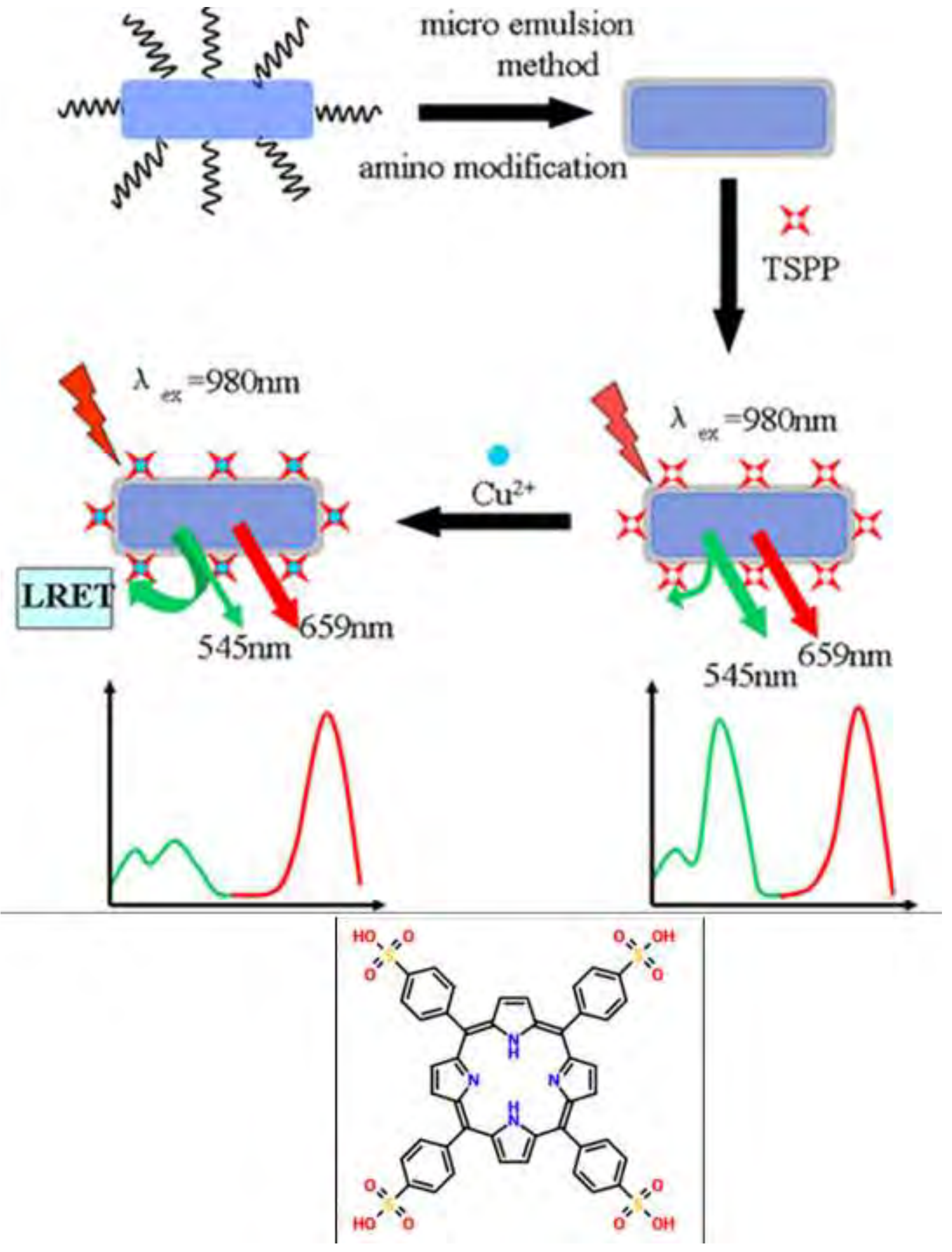


Graphical Abstract (for review)

Dye-Assembled Nanocomposites for Rapid Upconversion Luminescence Sensing of $\mathrm{Cu}^{2+}$

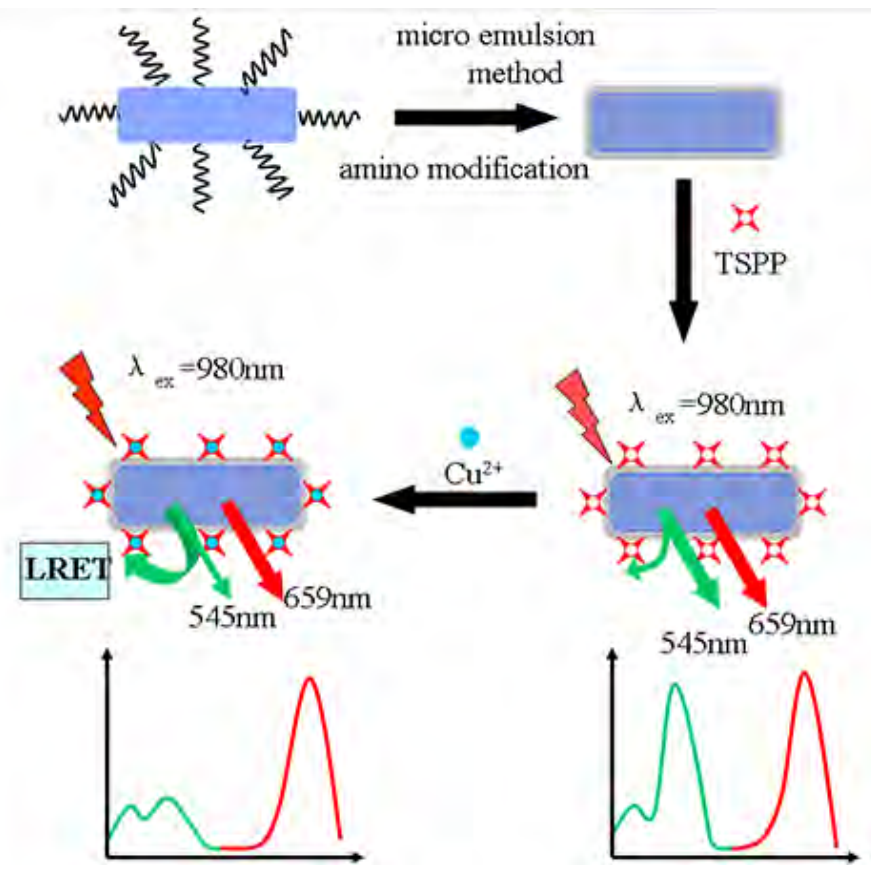


Fig.1A

Click here to download high resolution image

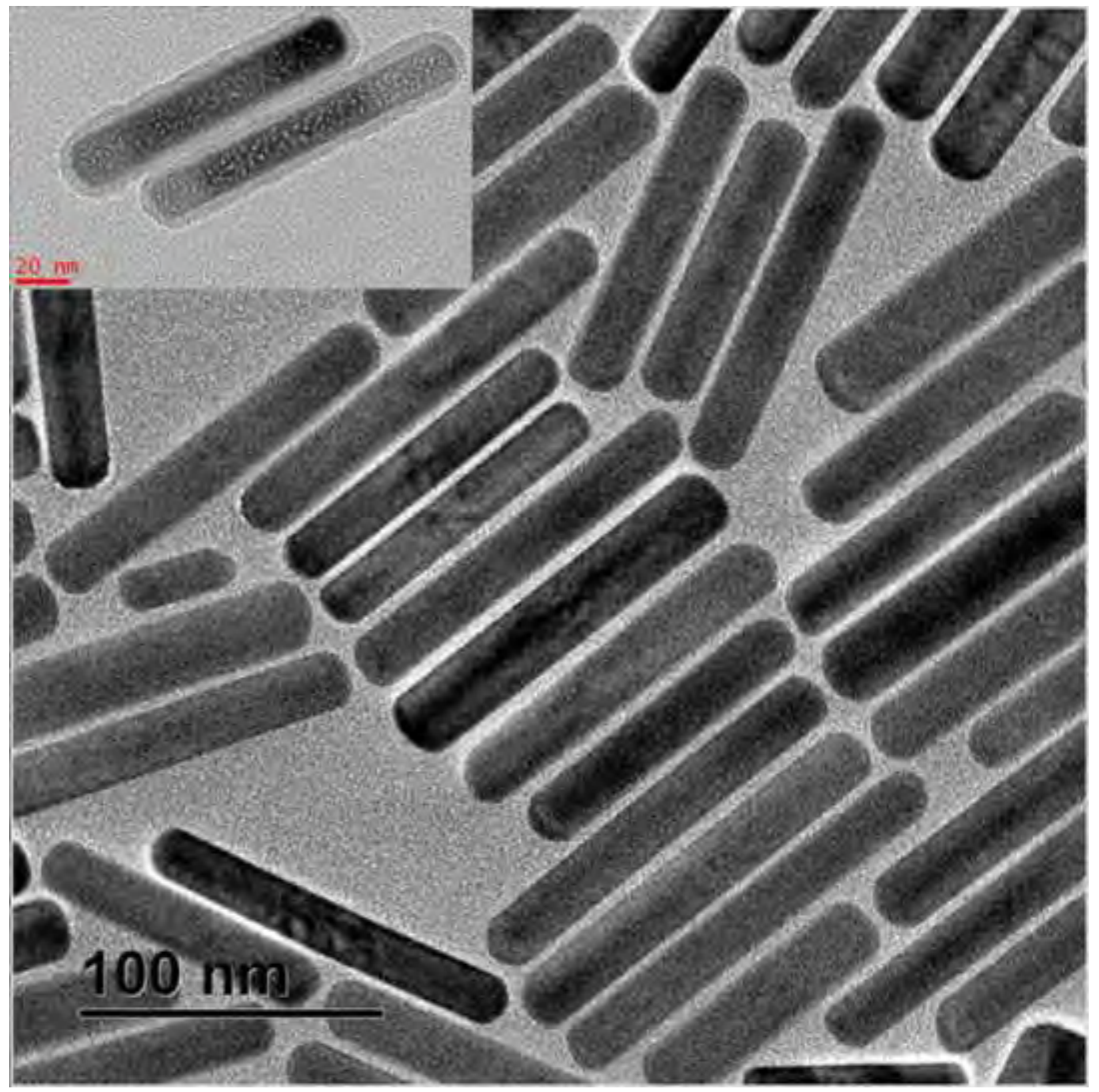




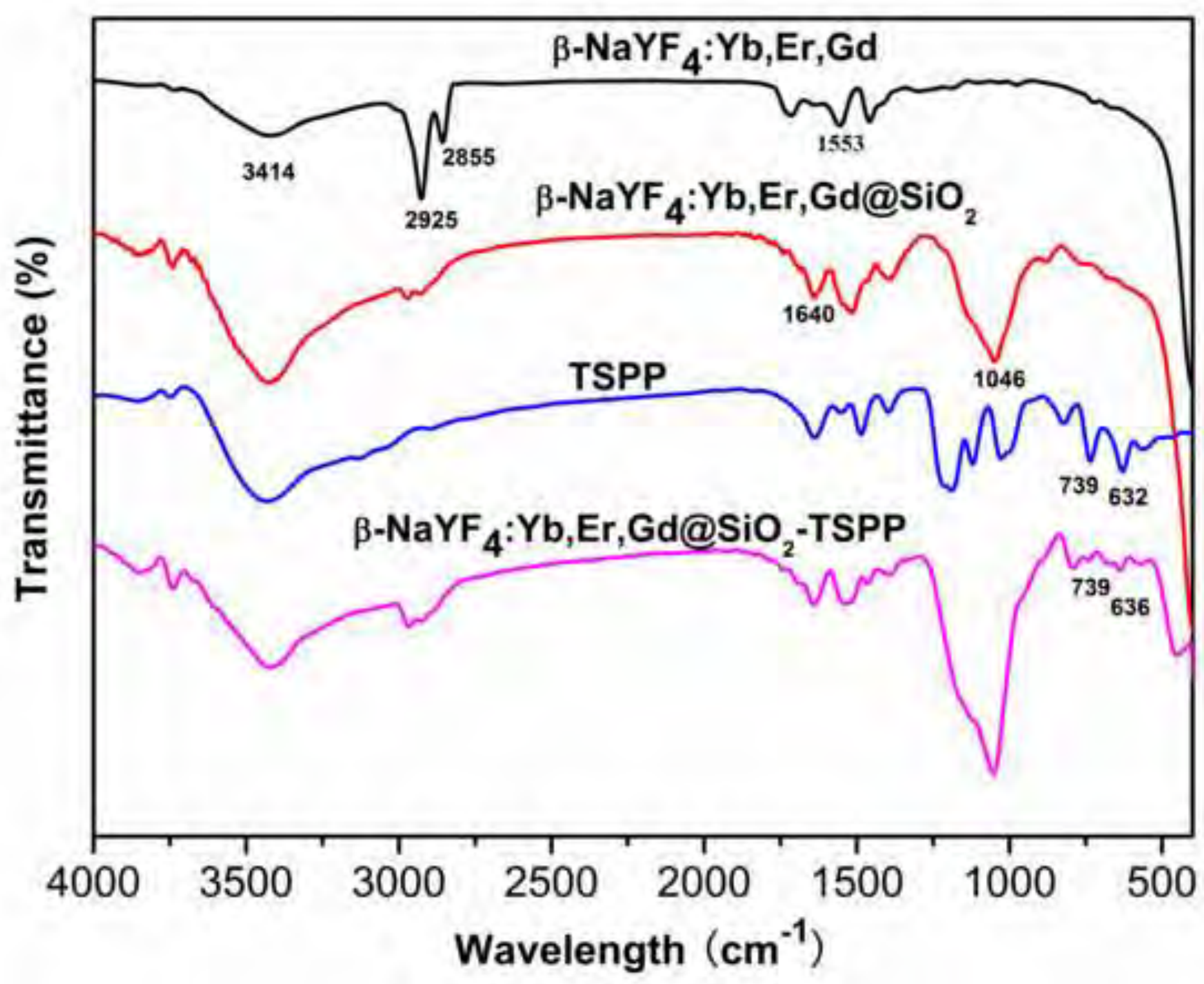




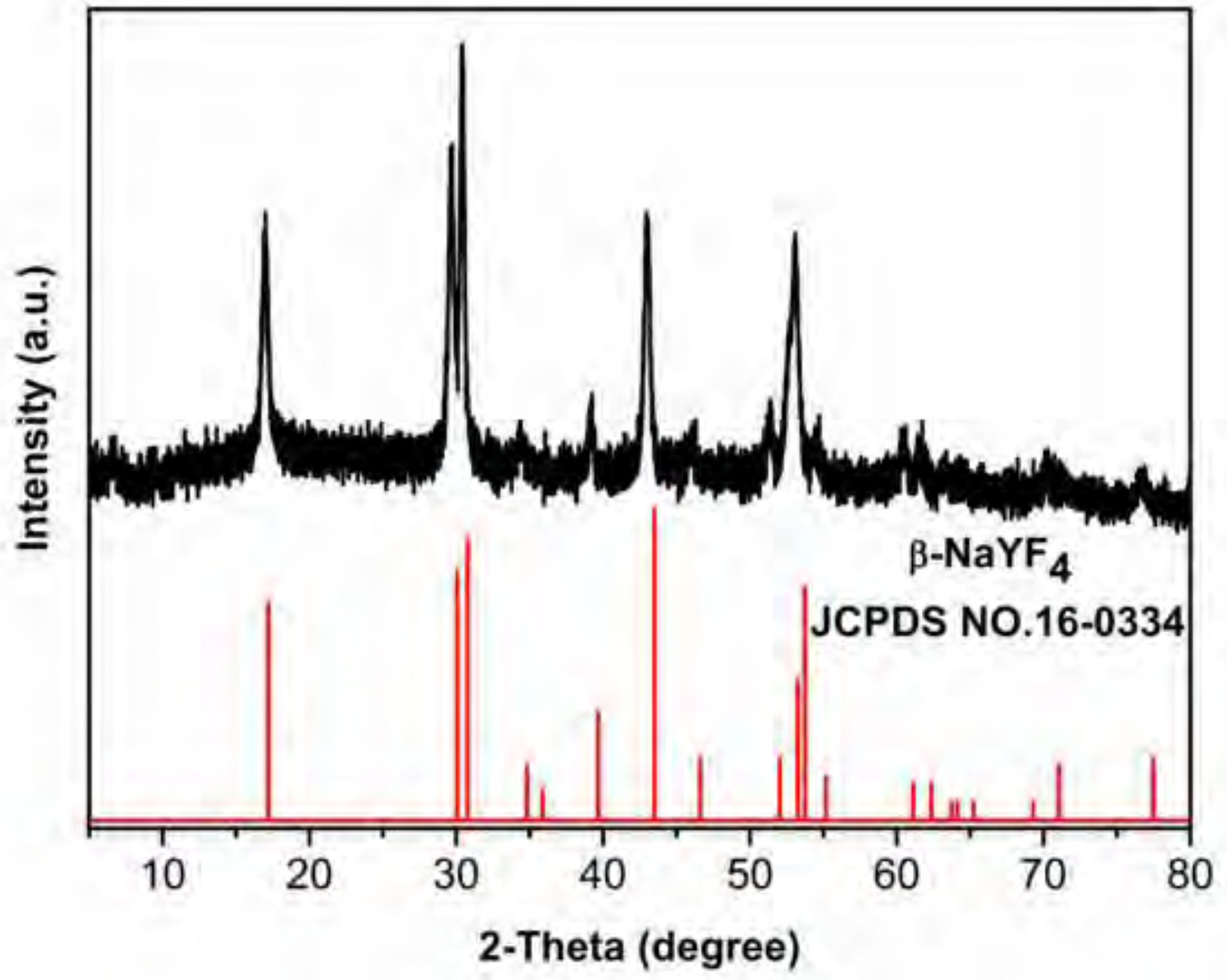




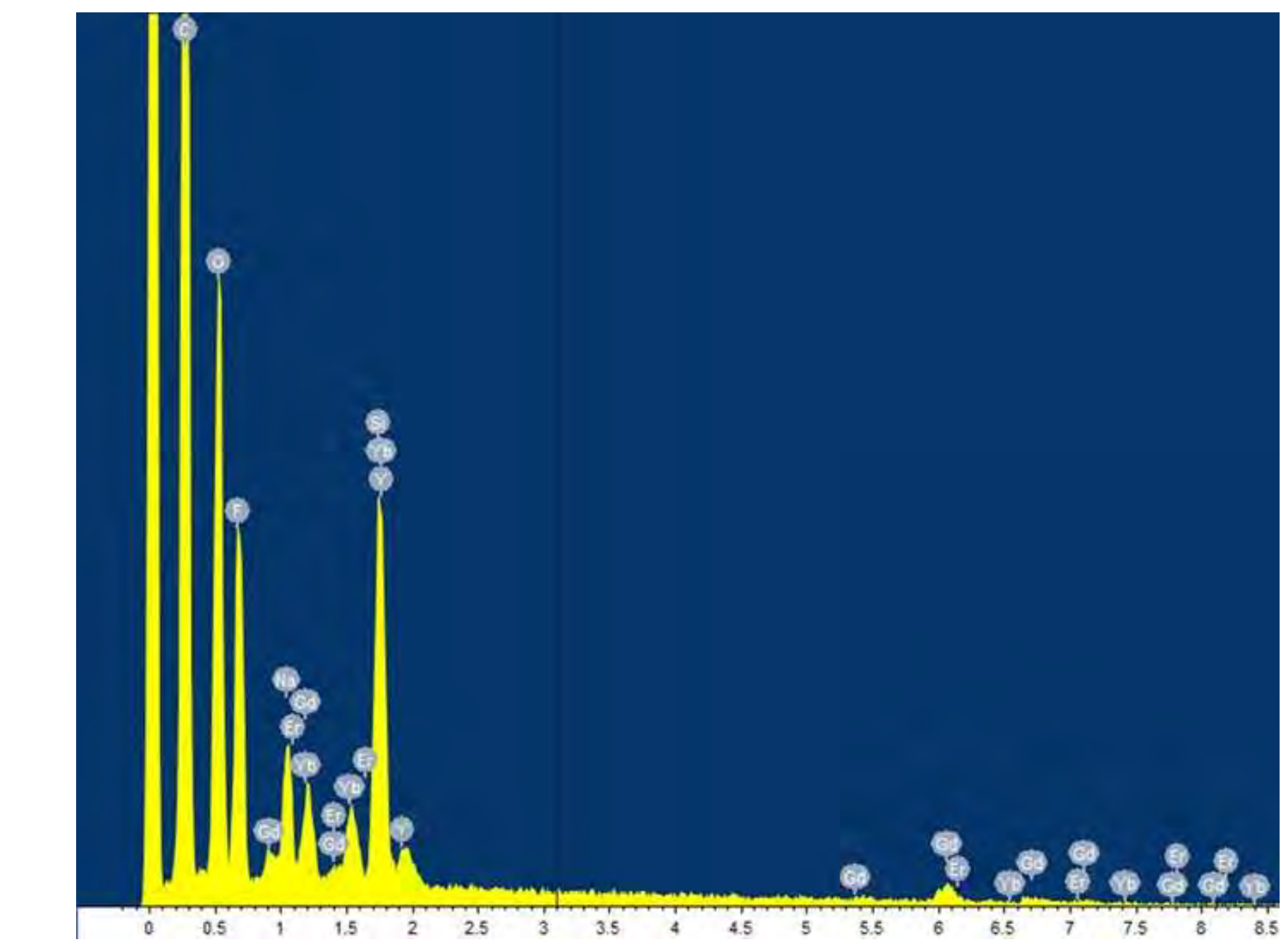




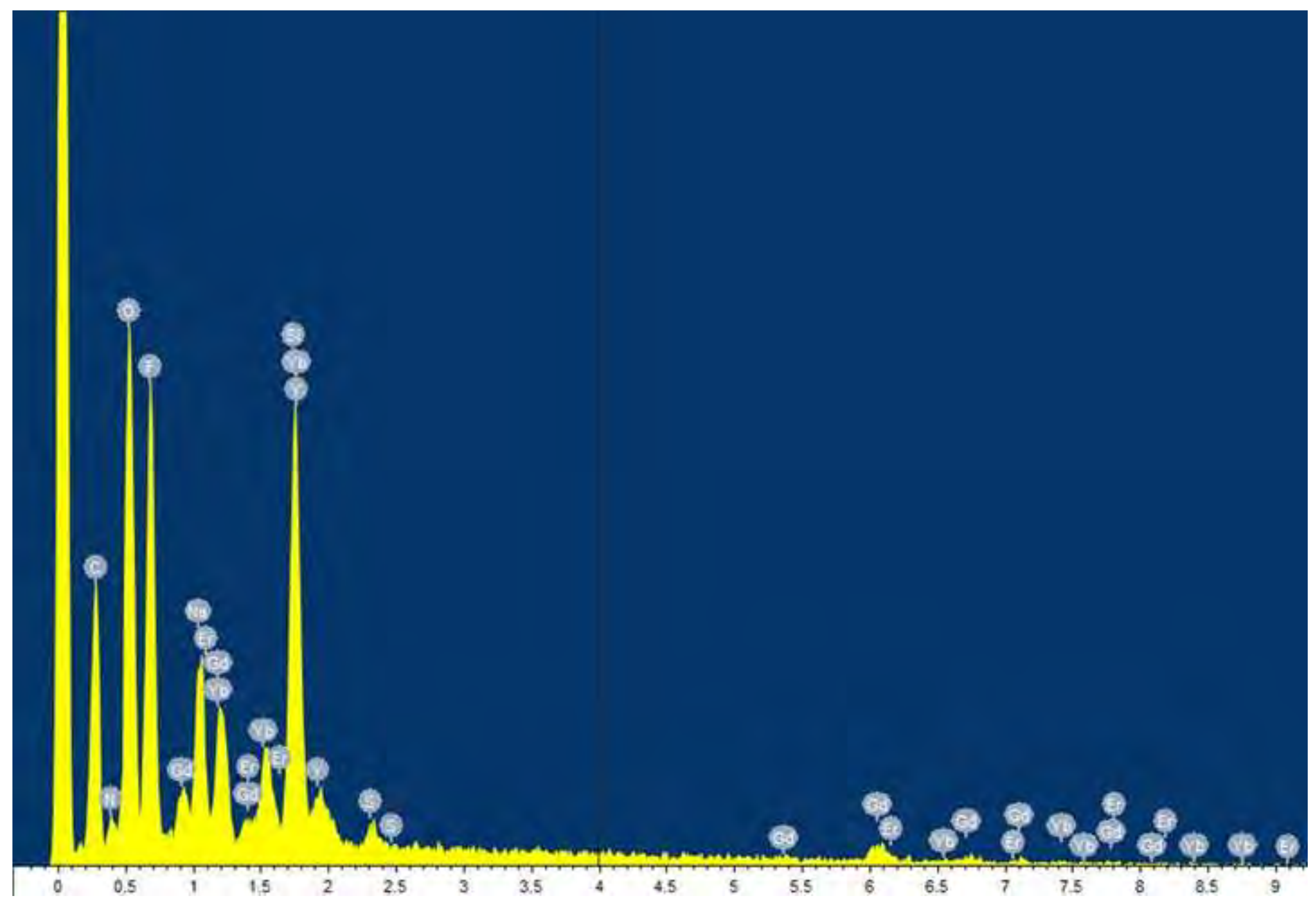

\section{click here to download high resolution image}




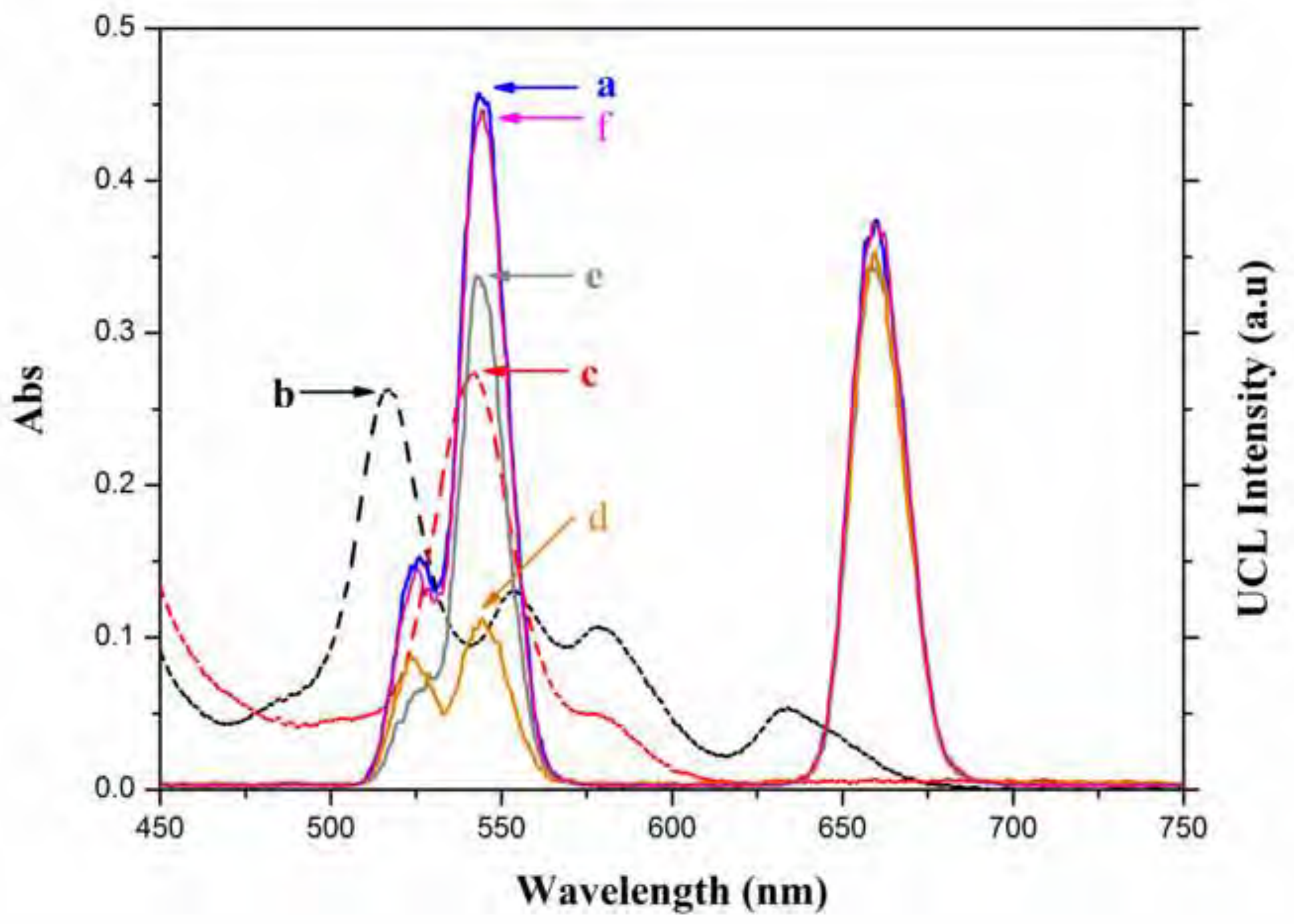




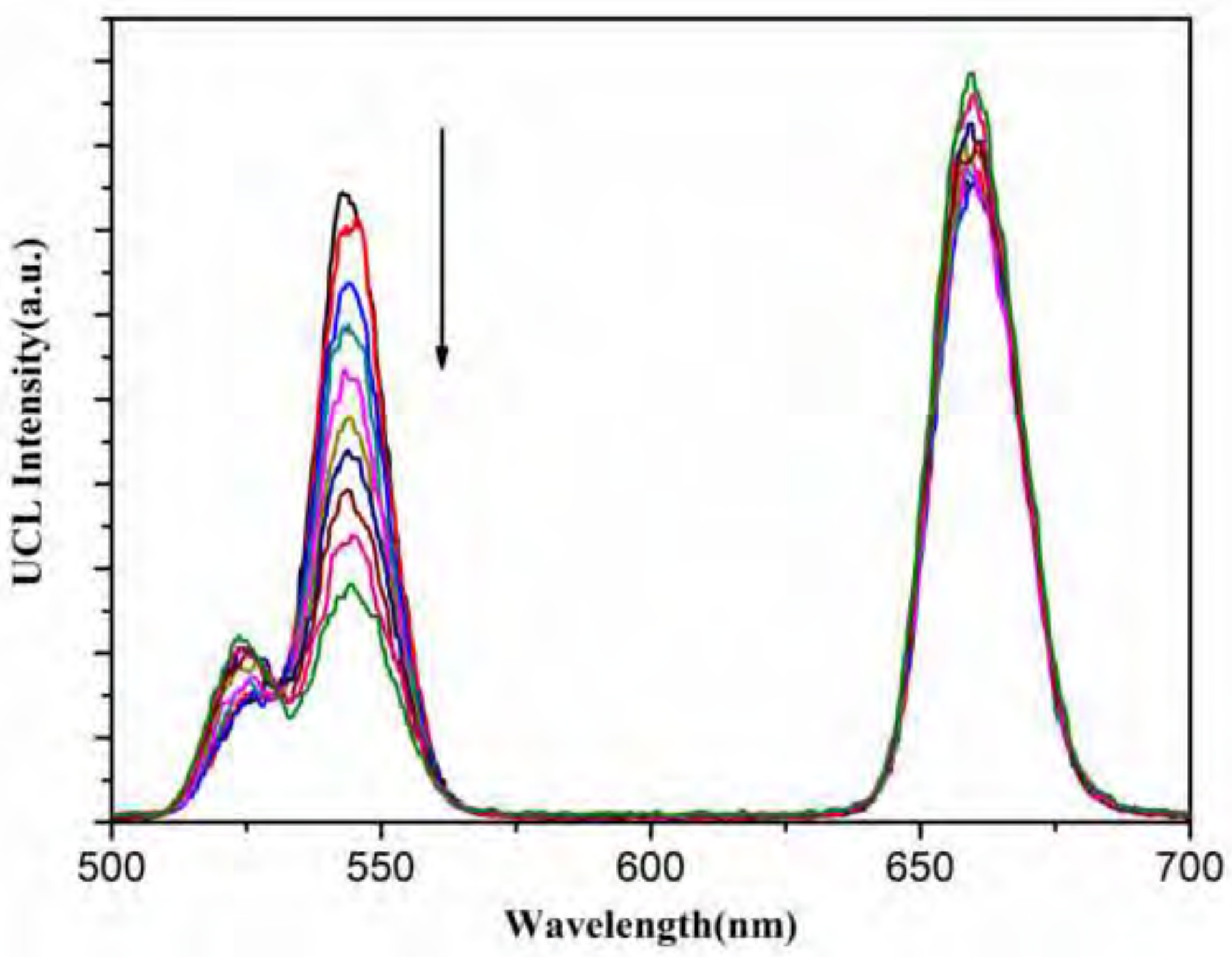




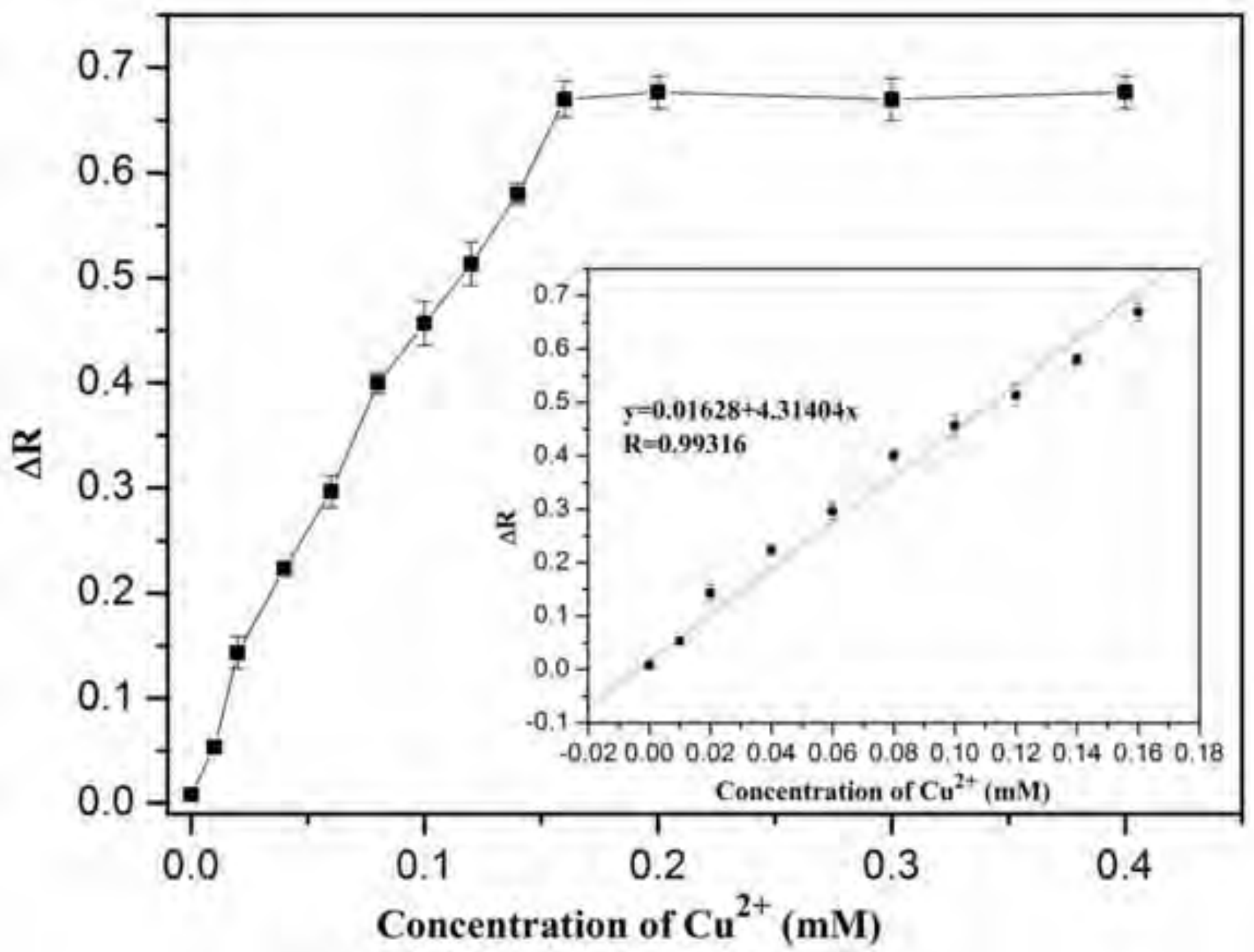




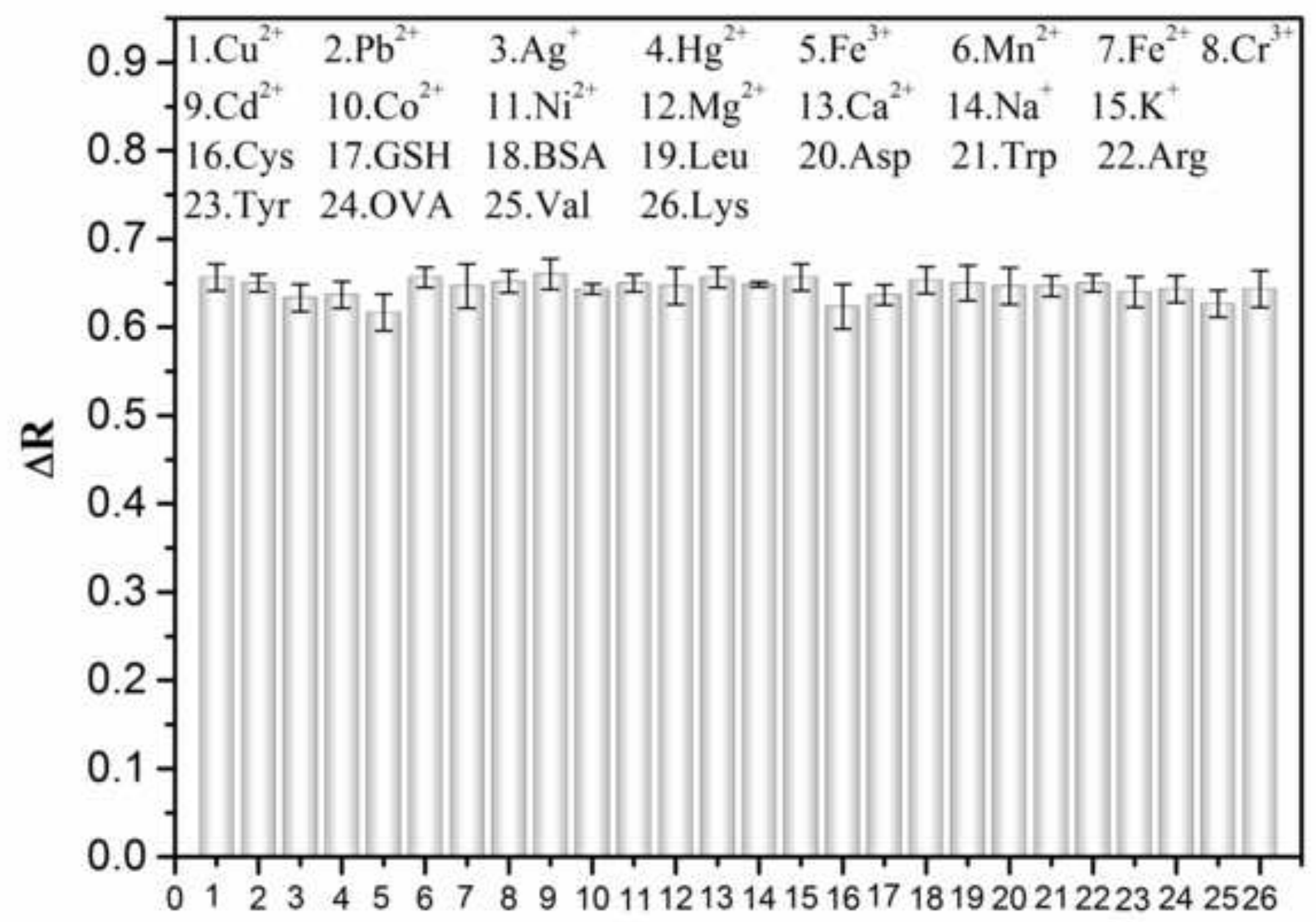




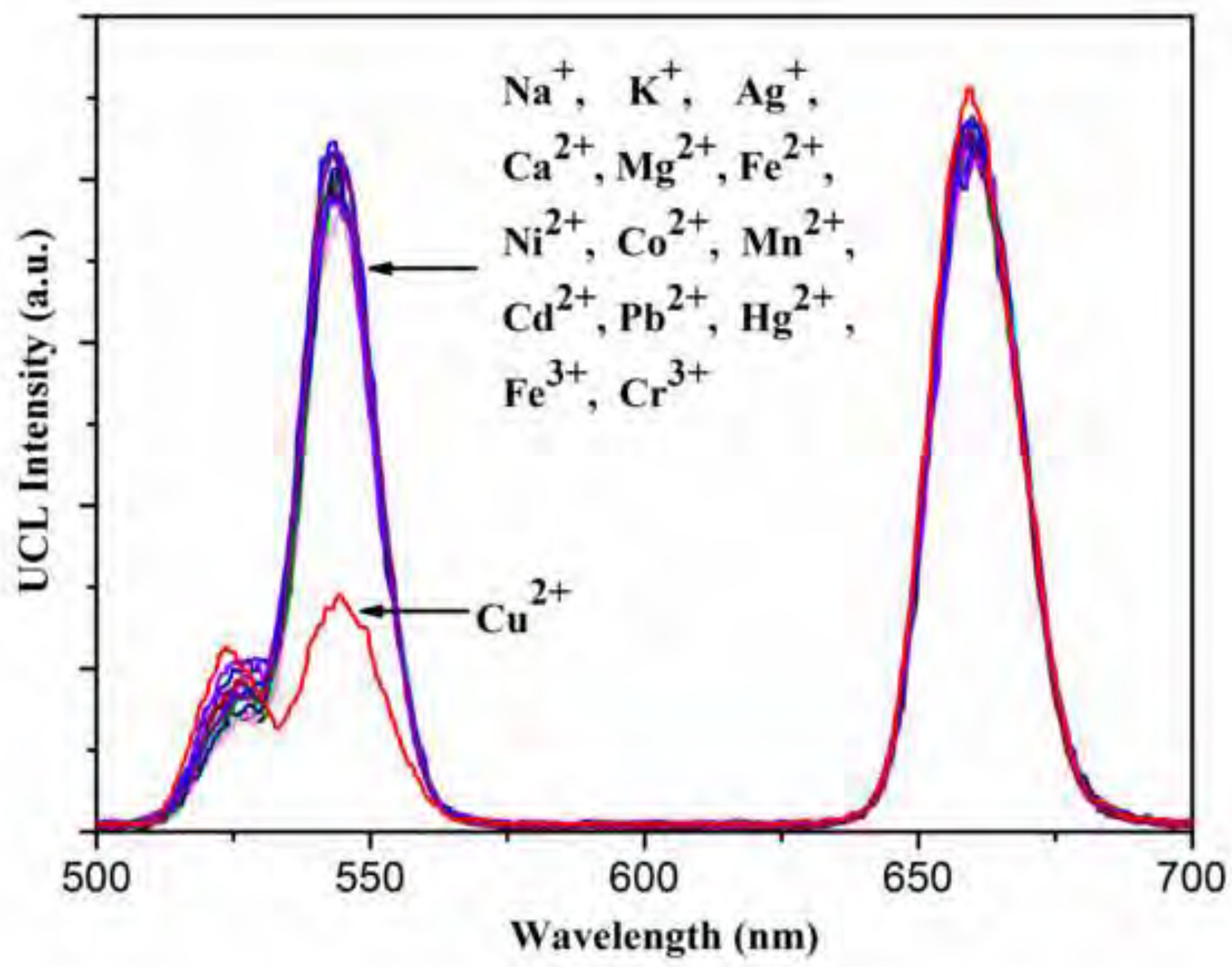




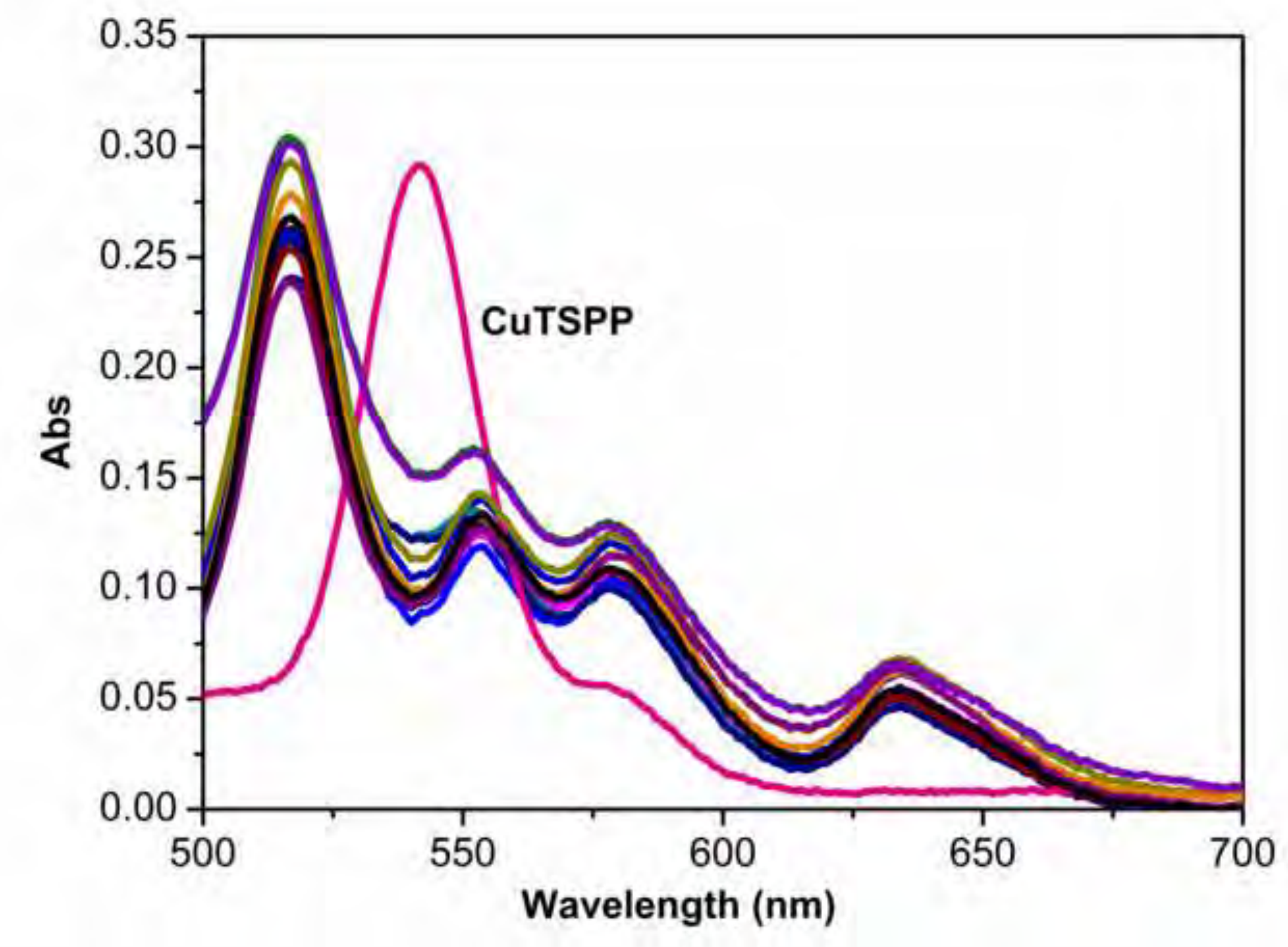

wion 
Supplementary Material
Click here to download Supplementary Material: Supplementary Material.doc

Supplementary Material
Click here to download Supplementary Material: Supplementary Material.doc

c

$\sqrt{10}$

$\sqrt{10}$

$\sqrt{10}$

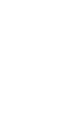

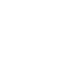

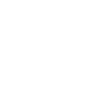
.

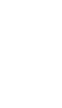

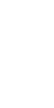

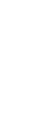
. (n) (n)

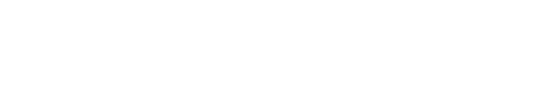

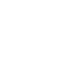


Xiaohua Huang received her B.Eng. in College of Chemistry and Chemical Engineering in 2014 from Jishou University, Jishou, China. She is a master course student in Hunan University. Her current interests are biosensors and rare earth nanomaterials.

Lijia Wang received her B.Eng. (2011) in Chemical Engineering from Guizhou University and M.Sc. (2014) in Analytical Chemistry from Shaanxi Normal University. She is currently pursuing a $\mathrm{PhD}$ degree under the supervision of Prof. Qingyun Cai in the Department of Chemistry and Chemical Engineering at Hunan University. Her research interests include design and synthesis of rare earth nanostructured materials for applications in drug dervery.

Xiaojun Zhang is a senior engineer. He received his B.Eng. in electrical engineering from Xi'an Jiaotong University in 1992 and M. Eng. in electrical engineering from Wuhan University of Hydraulic and Electric Engineering in1995. He mainly engaged in high voltage and insulation technology research, electricity management work.

Xuehua Yin received her B.Sc. in School of science in 2013 from Xiangtan University and M.Sc. in Analytical Chemistry in 2016 from Hunan University.

Na Bin received her B.S.c. in School of science in 2014 from Jiangsu University, Zhenjiang, China. She is a master course student in Hunan University. Her current interests are biosensors and electrochemistry.

Fenfen Zhong received her B.Sc. in School of science in 2014 from Henan Normal University, Henan, China. She is a master course student in Hunan University. Her current interests are chemical sensor and photoelectrochemistry.

Yingju Liu received her B.Sc. degree in 2000 and Ph.D. in chemistry in 2005 from 
Hunan University. She is currently a full-time professor in the Department of Applied Chemistry, College of Materials and Energy, South China Agricultural University, Guangzhou, China. Her primary research interests concern the biosensor and nanomaterials.

Qingyun Cai received his B.Sc. degree in 1983 and M.Sc. degree in 1986, both in chemistry from Hunan University, PR China. Since then he has been on the faculty at Hunan University. He earned his Ph.D. in chemistry in 1996 from Hunan University. From 1997 to 2001, he left to the University of Michigan and the University of Kentucky as a visiting scholar. He is currently a full-time professor in the Department of Chemistry at Hunan University, PR China. His primary research interests concern the chem/biosensor and functional (nano) materials. 